UDK: 632.51

Pregledni rad - Review article

\title{
Razvoj herbologije u Srbiji
}

\author{
Vaskrsija Janjić1 ${ }^{1}$ Momčilo Kojić2, Sava Vrbničanin², Branko Konstantinovićc \\ ${ }^{1}$ Akademija nauka i umjetnosti Republike Srpske, Bana Lazarevića 1, \\ 78000 Banja Luka, Republika Srpska, Bosna i Hercegovina \\ 2Univerzitet u Beogradu, Poljoprivredni fakultet, Nemanjina 6, 11080 Beograd-Zemun, Srbija \\ ${ }^{3}$ Univerzitet u Novom Sadu, Poljoprivredni fakultet, Trg Dositeja Obradovića 8, \\ 21000 Novi Sad, Srbija
}

\section{UVOD}

Herbologija (herba-trava, biljka, logos-nauka) je naučna, stručna i nastavna disciplina koja se bavi korovskim biljkama u najširem smislu i merama za njihovo suzbijanje. Naziv nije upotpunosti adekvatan, jer u prevodu herbologija znači nauka o biljkama uopšte i korisnim i štetnim, a mi pod ovim podrazumevamo samo korovske biljke i njihovu kontrolu, odnosno suzbijanje. Ovaj naziv je odomaćen i u upotrebi je da bi se oblast koja se bavi korovima kao štetnim agensima označila posebnim imenom poput fitopatologije (nauke o fitopatogenim mikroorganizmima, prouzrokovačima bolesti biljaka) i entomologije (nauke o štetnim insektima koji koriste biljke za svoju ishranu). Ovaj naziv koristi se i u nekim evropskim zemljama (npr. Franuskoj, Italiji, Nemačkoj), a skoro je nepoznat u anglosaksonskim zemljama. U ovim zemljama koristi se termin weed science. Herbologija je relativno mlada naučna disciplina, posebno nastavna, mada je interesovanje čoveka za korove staro koliko i zemljoradnja, odnosno poljoprivredna proizvodnja,te se korovi sa punim pravom označavaju kao arheofite i antropofite.

Problem korova kao posebne kategorije biljaka antropogenih sredina bio je predmet interesovanja već duže vreme u okviru drugih naučnih disciplina, pre svega u botanici (posebno floristici i fitocenologiji), kao i u nekim poljoprivrednim disciplinama koje se bave agrotehnikom i gajenjem poljoprivrednih biljaka (npr. Opšte i Posebno ratarstvo). Međutim, to nije bio sistematizovan, osmišljen pristup rešavanju mnogobrojnih i raznovrsnih problema korova kao posebne kategorije vrlo dinamičnih i karakterističnih biljnih vrsta, koje se nalaze pod vrlo snažnim antropogenim uticajem i koje su u savremenim uslovima gajenja biljaka postajale sve veći problem. 
Herbologija kao naučna, stručna i nastavna disciplina sastavljena je iz dva uzajamno povezana dela, a to su:

- Biologija korova (morfologija, fiziologija, sistematika, ekologija, fitocenologija i horologija korovskih biljaka) i

- Borba protiv korova, suzbijanje ili kontrola korova, gde dolaze dve grupe mera i to indirektne mere (mere koje predupređuju pojavu korova i zakorovljenost) i direktne mere (agrotehničke mere, fizičke mere, biološke mere, hemijske mere tj. primena herbicida).

Ova dva pravca u oblasti naučnog i stručnog angažovanja o problemima korova dugo su se razvijala odvojeno i nesinhronizovano, tako da se pre može govoriti o razmatranju i analizi nekih herboloških problema u okviru drugih naučnih disciplina nego o jednoj celovitoj, struktuiranoj i sveobuhvatnoj naučnoj disciplini koja se bavi korovima. U našoj zemlji, a slična je situacija u Evropi i u svetu, pre Drugog svetskog rata nauka o korovima, odnosno herbologija, kao posebna naučna i stručna disciplina nije ni postojala. Zabeležena su samo neka fragmentalna zapažanja u oblasti rasprostranjenosti korova i nekim agrotehničkim merama za njihovo suzbijanje. Tridesetih godina prošlog veka pojavile su se samo tri knjižice (brošure) koje su napisali Jarakula (1933), Kodinec (1937) i Martinović (1942). To su prve posebne publikacije o korovima kod nas, dok je pre toga, u skromnoj formi pisano o borbi protiv korova u okviru agrotehničkih mera u Opštem ratarstvu.

Pojava herbicida - hemijskih jedinjenja i njihovih preparata za suzbijanje i kontrolu korova predstavlja prekretnicu u razvoju naših znanja o problemima korova, posebno o merama za njihovo suzbijanje. To se dešava četrdesetih godina prošlog veka, 1938. godine kada je Irvin otkrio beta - nafta sirćetnu kiselinu, kao fiziološki aktivno hemijsko jedinjenje, što je doprinelo da Pokorni 1941. godine izvrši sintezu herbicida 2,4-D (2,4- dihlorfenoksi sirćetna kiselina). Od tada pa do danas sintetisan je ogroman broj herbicida na bazi različitih hemijskih jedinjenja. To je uvelo pravu revoluciju u ovu oblast i može se smatrati da tada počinje formiranje prave naučne i stručne discipline - nauke o korovoma (Weed Science) koja je kasnije u nekim zemljama označena kao herbologija, u kojoj po prirodi stvari participiraju biologija korova i mere za njihovu kontrolu, odnosno suzbijanje gde su uključeni i herbicidi.

Tako i u našoj zemlji razvoj herbologije, kao naučne i stručne discipline praktično počinje posle Drugog svetskog rata, sredinom četrdesetih godina prošlog veka. U našoj zemlji tada počinje organizovan pristup rešavanju bioloških, agrotehničkih, a posebno hemijskih problema vezanih za problematiku korova. Kao faktički, institucionalizovan početak organizovanog stručnog angažovanja na rešavanju herboloških problema u našoj zemlji može se smatrati osnivanje Jugoslovenske komisije za korove pri Saveznoj privrednoj komori, 1955. godine. U tu Komisiju imenovani su istaknuti stručnjaci i naučni radnici koji su se bavili problematikom korova sa prostora tadašnje Jugoslavije, u kojoj su iz Srbije bili Vojislav Novaković, Stojan Čuturilo i Momčilo Kojić. Godinu dana kasnije, 1956. godine, održava se Prvo savetovanje o borbi protiv korova, pod pokroviteljstvom Saveta Akademija nauka FNRJ, a u organizaciji Saveza poljoprivrednih komora Jugoslavije. Ovaj skup, prvi u Evropi, može se smatrati da predstavlja pravi početak razvoja herbologije, kao naučne i stručne discipline u našoj zemlji. 
Prvo zvanično državno telo, koje je imalo zadatak da se bavi problemima korova, bila je Jugoslovenska komisija za borbu protiv korova, koju je osnovao Savet Jugoslovenskog poljoprivredno-šumarskog centra 24. marta 1969. godine. Komisiju je sačinjavalo 18 članova sa područja cele tadašnje Jugoslavije među kojima su bili: Josip Kovačević (Zagreb), Josip Kišpatić (Zagreb), Aleksandar Stanković (Novi Sad), Risto Lozanovski (Skoplje), Taib Šarić (Sarajevo), Momčilo Kojić (Beograd), Vojislav Novaković (Beograd) i Stojan Čuturilo (Beograd). Predsednik Komisije je bio Stojan Novaković. U odluci o osnivanju ove Komisije (br.01-974/1) ističe se da je Komisija formirana sa ciljem da radi na unapređenju mera koje se predizimaju u oblasti borbe protiv korova i to:

- Organizuje jugoslovenska savetovanja o borbi protiv korova i publikuje materijale sa savetovanja;

- Pruža pomoć kod organizovanja regionalnih savetovanja o borbi protiv korova;

- Podstiče i koordinira rad u oblasti proučavanja korova i borbe protiv njih;

- Pomaže kod izrade regionalnih planova;

- Podstiče i koordinira rad na proučavanju korovske flore Jugoslavije i radi na njenom evidentiranju i kartiranju;

- Radi na proučavanju stručne i naučne terminologije iz ove oblasti, posebno na njenom usvajanju;

- Podstiče i koordinira rad na ispitivanju herbicida u proizvodnim i drugim uslovima, objedinjavanjem metodike ispitivanja;

- Sprovodi organizovane diskusije o vrednosti pojedinih herbicida sa šireg regionalnog aspekta;

- Podstiče podizanje i stvaranje stručnjaka specijalista za proučavanje korova;

- Vodi evidenciju postojećeg kadra specijalista za proučavanje korova;

- Radi na izmeni i širenju informacija iz oblasti borbe protiv korova i njihovog proučavanja;

- Održava vezu sa sličnim organizacijama u zemlji i inostranstvu;

- Daje predloge i mišljenja u vezi sa donošenjem neophodnih zakonskih propisa iz oblasti borbe protiv korova.

U Sarajevu je 1973. godine formirano Jugoslovensko društvo za proučavanje i suzbijanje korova, a predsednici Društva su bili: prvi prof. dr Josip Kovačević, a zatim prof. dr Taib Šarić. Raspadom zemlje, u Srbiji, angažovanjem akademika Vaskrsija Janjića i prof. dr Momčila Kojića, formirano je Herbološko društvo Srbije koje i danas funkcioniše i u čijoj organizaciji se odvija celokupna aktivnost Društva. Predsednik Društva od njegovog osnivanja 1992. godine do danas je akademik Vaskrsija Janjić. Od tada sve aktivnosti u oblasti herbološke nauke odvijale su se u organizaciji Herbološkog društva Srbije.

Razvojni put nauke o korovima prikazaće se valorizacijom osnovnih akcenata iz 75 godišnje aktivnosti jugoslovenskih i srpskih stručnjaka u dva osnovna domena herbologije, a to su:

- Naučni i stručni aspekti razvoja herbologije i

- Početak i razvojni put herbologije kao nastavne discipline 


\section{RAZVOJ HERBOLOGIJE KAO NAUČNE I STRUČNE DISCIPLINE}

Bez obzira što je naučna i stručna aktivnost vezana za korove, obeležena čak i zapaženim rezultatima, započela odmah posle Drugog svetskog rata, suštinski osmišljen i organizovan rad na problematici korova započinje desetak godina kasnije. Naime, 17- 19 januara 1956. godine održano je Prvo savetovanje o borbi protiv korova, na inicijativu Akademijskog saveta FNRJ i Saveza poljoprivrednih komora Jugoslavije. Na ovom skupu udareni su temelji stručne i naučne aktivnosti u oblasti proučavanja i suzbijanja korova. Osnovni pečat u radu ovog Savetovanja dali su istaknuti stručnjaci botaničke i agrotehničke orijentacije toga vremena, univerzitetski profesori Dobroslav Todorović, član Srpske akademije nauka i umetnosti (Beograd), Živko Slavnić (Novi Sad) i Josip Kovačević (Zagreb). Savetovanje je otvorio prof. Siniša Stanković. U uvodnim referatima oni su ukazali na bitne probleme koji je trebalo proučavati i rešavati u okviru problematike korova, kao što su:

- Značaj florističkih i ekobioloških proučavanja korova za teoriju i praksu (Živko Slavnić);

- Problematika savremene borbe protiv korova (Dobroslav Todorović);

- Metodika za proučavanje korova (Josip Kovačević).

Pored ovih, na ovom Savetovanju saopšteno je još 16 referata iz tri tematske oblasti koje se predstavljale osnovu daljih istraživanja i drugih aktivnosti u oblasti herbologije, a to su:

- Biologija korova

- Borba protiv korova i

- Organizacija borbe protiv korova

Rezultati, diskusija i zaključci Prvog savetovanja o korovima u suštini predstavljaju osnovu utemeljenja problematike korova kao naučne i stručne discipline u Jugoslaviji. O tome ubedljivo ukazuju osnovni zaključci i predlozi ovog prvog herbološkog skupa. Da bi se pristupilo organizovanju sistematskog proučavanja rasprostranjenja korova u našoj zemlji, njihove biologije i ekologije, kao i načina borbe bilo je potrebno:

- Organizovati plansku i sistematsku borbu protiv korova u celoj zemlji i to kako u oblasti celokupne poljoprivrede, tako i u oblasti šumarstva, vodoprivrede, saobraćaja, itd.

- Pristupiti izradi i publikovanju jednog udžbenika o korovima.

Insistiranjem da se izda udžbenik o korovima, plediralo se na uvođenju nastavne discipline o korovima, što je ostvareno početkom sedamdesetih godina prošlog veka. Posle Prvog savetovanja o borbi protiv korova, 1956. godine, dolazi do vrlo intenzivne aktivnosti na polju proučavanja biologije korova (posebno sa fitocenološkog gledišta) i primene mera (u prvom redu herbicida) za njihovo suzbijanje. Održan je veliki broj savetovanja, simpozijuma i kongresa iz ove oblasti. U početku organizator je bila Jugoslovenska komisija za borbu protiv korova, a zatim Jugoslovensko društvo za proučavanje i suzbijanje korova i najzad Herbološko društvo Srbije. 
U periodu od 1955. do 1975. godine održano je 11 jugoslovenskih savetovanja o borbi protiv korova. Na ovim savetovanjima opšteg tipa razmatrana su sva pitanja herbološke problematike, a posebno problemi primene herbicida i njihove efikasnosti u raznim poljoprivrednim kulturama.

Naučne i stručne skupove privremeno su organizovale i specijalizovane ustanove i preduzeća. Hemijska industrija „Zorka“ iz Šapca, HI „Župa“ iz Kruševca i HI „Zorka“ iz Subotice organizovale su nekoliko skupova o primeni pesticida. U periodu 1969-1979. godina značajnu ulogu u okupljanju stručnjaka iz zaštite bilja imala je „Agrovojvodina“ iz Novog Sada. Ta firma je od 1969. godine organizovala deset savetovanja, u početku o zaštiti bilja, a kasnije o pesticidima. Svi ovi skupovi, izuzev prva tri, održavani su u Poreču na kraju svake kalendarske godine. Na ovim skupovima okupljalo se oko 1.000 stručnjaka, među kojima je bilo najviše onih koji su se bavili herbologijom.

Članovi Herbološkog društva Srbije dali su ogroman doprinos u organizaciji naučnih i stručnih skupova koje je organizovalo Društvo za zaštitu bilja Srbije i Jugoslavije (savetovanja o zaštiti bilja, simpozijumi o zaštiti bilja, kongresi o zaštiti bilja). Pored savetovanja opšteg tipa organizovano je i uspešno sprovedeno sedam savetovanja i simpozijuma i to:

- Simpozijum o travnim korovima (Ohrid, 1971. godine);

- Jugoslovenski simpozijum o borbi protiv korova u brdsko-planinskom području (Sarajevo, 1973. godine);

- Jugoslovensko savetovanje o borbi protiv korova u voćnjacima i vinogradima (Peć, 1976. godine);

- Jugoslovensko savetovanje o primeni herbicida na željezničkim prugama i nasipima (Zagreb, 1977. godine);

- Jugoslovensko savetovanje o suzbijanju korova avionima i helikopterima (Osijek, 1978. godine);

- Jugoslovensko savetovanje o suzbijanju korova u šumarstvu (Sarajevo,1979. godine) i

- Simpozijum o ambroziji (Beograd, 2007. godine).

Veoma je važno istaći, da su u našoj zemlji organizovana i tri međunarodna simpozijuma sa herbološkom problematikom i to:

- International symposium of wild oats (Međunarodni simpozijum o divljem ovsu) (Zaječar, 1979. godine);

- $2^{\text {th }}$ International symposium of aquatic weeds (Drugi međunarodni simpozijum o akvatičnim korovima) (Novi Sad, 1982. godine) i

- $6^{\text {th }}$ International symposium of herbivore fishes (Šesti međunarodni simpozijum o biljojednim ribama) (Novi Sad, 1982. godine).

Novi kvalitet u naučno-satručnoj aktivnosti u oblasti herbologije predstavlja odluka Jugoslovenskog društva za proučavanje i suzbijanje korova o organizaciji herboloških kongresa - kao najvišeg stepena naučne valorizacije proučavanja korova. Predviđeno je tada, a tako je i ostvareno, da se u četverogodišnjem intervalu održavaju kongresi o korovima, koji 
će biti smotra naučno-istraživačkih aktivnosti u oblasti biologije i suzbijanja korova. Počevši od 1980. godine, kada je održan Prvi kongres o korovima, u redovnom terminu u mesecu junu (osim IX Kongresa koji je održan u novembru zajedno sa Savetovanjem o zaštiti bilja), pa do danas, svake četvrte godine, održano je devet kongresa i to:

- I kongres korovima (Banja Koviljača, 1980. godine);

- II kongres korovima (Osijek, 1984. godine);

- III kongres korovima (Ohrid, 1988. godine);

- IV kongres korovima (Banja Koviljača, 1992. godine);

- V kongres korovima (Banja Koviljača, 1996. godine);

- VI kongres korovima (Banja Koviljača, 2000. godine);

- VII kongres korovima (Subotica, 2004. godine);

- VIII kongres korovima (Vrnjačka Banja, 2008. godine);

- IX kongres korovima (Zlatibor, 2012. godine).

Na taj način održavao se kontinuitet i redovnost u održavanju najviših naučnih skupova iz oblasti herbologije. Gotovo na svim ovim kongresima učestvali su sa referatima stručnjaci iz inostranstva među kojima i članovi Evropskog društva za korove (EWRS). Prvom kongresu o korovima prisustvovali su predsednik Evropskog društva za korove i presednik Svetskog društva za korove. Najveći doprinos uspešnoj organizaciji ovih naučnih skupova dali su akademik prof. dr Vaskjrsija Janjić, koji je na I kongresu bio generalni sekretar, a od tada skoro na svim kongresima predsednik Naučnog ili Organizacionog odbora i prof. dr Momčilo Kojić, prvi nastavnik predmeta Korovi na Poljoprivrednom fakultetu Univerziteta u Beogradu. Aktivno učešće u organizaciji Kongresa, u svojstvu predsednika Organizacionih ili Programskih odbora, dali su i: prof. dr Zvonko Ostojić, dr Ivan Šilješ, dr Ana Skender, dr Marija Arsenović, akademik prof. dr Risto Lozanovski, prof. dr Sava Vrbničanin, dr Goran Malidža i dr Dragana Marisavljević.

Da bi se dobila reljefnija slika o aktuelnosti i izuzetnom značaju herboloških problema koji su analizirani i o kojima se raspravljalo na kongresima o korovima, a na osnovu kojih se utvrđivalo stanje i davale smernice za dalji razvoj naučnog i stručnog rada, dajemo pregled uvodnih referata sa svih dosadašnjih kongresa, koji su odražani u periodu od 1980. do 2012. godine.

\section{I kongres o korovima (1980. godina)}

Savremeni problemi proučavanja korovske flore i vegetacije s posebnim osvrtom na metode istraživanja (Momčilo Kojić);

1. Značaj korova i herbicida u proizvodnji hrane i zaštiti čovekove okoline (Taib Šarić);

2. Uloga i značaj korova za opštenarodnu odbranu (Vaskrsija Janjić);

3. Obrazovanje kadrova u herbologiji (Taib Šarić, Dikonije Božić i Risto Lozanovski);

4. Značaj agrotehničkih mera u borbi protiv korova (Dikonije Božić). 


\section{II kongres o korovima (1984. godina)}

1. Stanje, problemi i perspektive proučavanja korovske vegetacije u Jugoslaviji (Momčilo Kojić);

2. Promene florističkog sastava korovskih fitocenoza strnih žita i kukuruza usled dugoročne primene herbicida i drugih mera (Ksenija Mijatović i Risto Lozanovski);

3. Ekološki pristup ispitivanju praga štetnosti korova i primena u praksi (Josip Kišpatić, Ana Skender, Marija Ivezić i Ivan Šilješ);

4. Uloga kompleksa agrotehničkih mera u borbi protiv korova (Taib Šarić i Dikonije Božić);

5. Stanje, problemi i tendencije proizvodnje i potrošnje herbicida u našoj zemlji (Vaskrsija Janjić i Sofija Jevtić);

6. Uticaj herbicida na intenzitet razvoja nekih bolesti kulturnog bilja (Josip Kišpatić);

7. Energetske osnove borbe protiv korova (Risto Lozanovski)-ž.

\section{III kongres o korovima (1988. godina)}

1. Istraživanja u oblasti biologije korova-stanje i perspektive (Momčilo Kojić);

2. Korovi, herbicidi i zaštita životne sredine (Vaskrsija Janjić i Dikonije Božić);

3. Problemi i metode kartiranja korovske flore i vegetacije (Jasenka Topić).

\section{IV kongres o korovima (1992. godina)}

1. Korovi, ekosistem i životna sredina (Momčilo Kojić);

2. Korovske zajednice i faktori sredine (Borivoj Šinžar, Lidija Stefanović i Mileta Živanović);

3. Osnovne hemijske, fiziološke, toksikološke i druge osobine herbicida sulfonilurea, imidazolinona i triazolopirimidina (Vaskrsija Janjić i Sofija Jevtić);

4. Toksikološki aspekti primene herbicida (Slavoljub Vitorović).

\section{V kongres o korovima (1996. godina)}

1. Prof. dr Momčilo Kojić - život, naučni, stručni i pedagoški rad (Vaskrsija Janjić, Sofija Pekić, Ranka Popović, Slobodanka Stojanović, Dragoslav Pejčinović i Risto Lozanovski);

2. Problemi biodiverziteta u agrarnim ekosistemima - Florobiodiverzitet u agrofitocenozama strnih žita i okopavina (Momčilo Kojić i Sava Ajder);

3. Savremena istraživanja prirode i delovanja herbicida (Vaskrsija Janjić);

4. Korovska flora u usevu kukuruza Srbije (Borivoj Šinžar, Lidija Stefanović i Jasna Šinžar);

5. Biodiverzitet korovske flore livadske vegetacije (Slavica Mrfat-Vukelić, Momčilo Kojić, Sava Ajder i Zora Dajić);

6. Razvoj herbicida, njihova sadašnjost i budućnost (Branko Konstatinović);

7. Uloga sistema zemljoradnje u kontroli korovske vegetacije (Dikonije Božić, Dušan Kovačević i Nebojša Momirović). 


\section{VI kongres o korovima (2000. godina)}

1. Razvoj herbologije u Jugoslaviji (Momčilo Kojić i Vaskrsija Janjić);

2. Biološka i ekološka istraživanja korova na području Srbije (razvoj, sadašnje stanje i perspektive) (Sava Vrbničanin i Momčilo Kojić);

3. Značaj ruderalne flore i potreba za njenim uništavanjem (Vaskrsija Janjić);

4. Baze georeferenciranih podataka i njihov značaj u mapiranju vegetacije (Branko Karadžić i Lidija Stefanović);

5. Biološka borba protiv korova-strategije, iskustva, aktuelni pravci i regulativa (Radmila Petanović, Zlata Klokočar-Smit i Radoslava Spasić);

6. Razvoj mehanizacije za aplikaciju herbicida (Nikola Đukić, Andrej Ponjičan i Rajko Bugarin);

7. Uloga integralnih sistema suzbijanja korova u konceptu održive poljoprivrede (Dušan Kovaćević i Nebojša Momirović);

8. Uvoz, proizvodnja i promet herbicida u SRJ (Radenko Stepić i Piljo Dakić).

\section{VII kongres o korovima (2004. godina)}

1. The Significance and Impact of Herbicide Resistant Weeds - a Global Overview (Baruh Rubin);

2. Genetičko - biohemijske osnove rezistentnosti korovskih biljaka prema herbicidima inhibitorima aceto laktat sintetaze (ALS) (Vaskrsija Janjić, Ljiljana Radivojević, Siniša Mitrić i Goran Malidža);

3. Adventivne i invazione korovske vrste na području Srbije (Sava Vrbničanin, Branko Karadžić i Zora Dajić- Stevanović);

4. Borba protiv korova u organskoj poljoprivredi (Dušan Kovačević i Nebojša Momirović);

5. Genetički modifikovane biljke tolerantne na herbicide - herbološki aspekt (Goran Malidža i Vaskrsija Janjić);

6. Ekotoksikološka procena rizika za pesticide - herbicide (Vesela Karan, Milica Mojašević, Slavoljub Vitorović i Ibrahim Elezović);

7. Socio-ekonomski aspekti suzbijanja korova u zemljama istočne Evrope (Lidija Stefanović i Milena Simić).

\section{VIII kongres o korovima (2008. godina)}

1. Prirodni proizvodi sa alelopatskim, herbicidnim i toksičnim delovanjem (Vaskrsija Janjić, Radmila Stanković - Kalezić i Ljiljana Radivojević);

2. Rezistentnost korova na herbicide u svetu i kod nas (Branko Konstantinović, Maja Meseldžija, Danijela Pavlović i Divna Marić);

3. Kompeticija - najčešći oblik interakcija između useva i korova (Milena Simić i Lidija Stefanović); 
4. Multivariate Analysis in Weed Vegetation Research - Ehample from NW Balkans (Urban Šilc i Sava Vrbničanin);

5. Uloga agrotehničkih mera u suzbijanju korova u savremenim konceptima razvoja poljoprivrede (Dušan Kovačević i Nebojša Momirović);

6. Critical Period of Weed Control - the Concept and Practical use (Stevan Knežević).

\section{IX kongres o korovima (2012. godina)}

1. Istorijat i pravci razvoja herbologije kao naučne i obrazovne discipline (Sava Vrbničanin i Vaskrsija Janjić);

2. Weed management in organic vegetable farming (Carlos Zaragoza);

3. Ispitivanje biološke aktivnosti i ponašanja herbicida biološkim metodama (Siniša Mitrić i Vaskrsija Janjić);

4. Perzistentnost herbicida i potencijalna opasnost za naredne biljke u plodoredu (Katarina Jovanović-Radovanov);

5. Analitičke metode za određivanje herbicida u zemljištu (Rada Đurović, Ljiljana Radivojević i Tijana Đorđević).

Iz pregleda uvodnih referata saopštenih na kongresima, može se bar donekle, sagledati sva kompleksnost i aktuelnost teorijskih i praktičnih problema savremene herbologije, koji su obrađeni i prezentovani, te su na taj način svi važniji aspekti različitih problema savremene nauke o korovima postali dostupni naučnoj i stručnoj javnosti herbološke orijentacije. Poseban kvalitet svih kongresnih zasedanja, kao i ostalih naučnih i stručnih skupova (simpozijuma i savetovanja), jeste u tome, što su svi referati, kako uvodni tako i ostali, štampani u celini u posebnim publikacijama (zbornicima) i to pre početka njihovog rada. Tako je, na Kongresima o korovima objavljeno preko 450 naučnih radova i skoro isto toliki broj na ostalim naučnim skupovima koji su organizovali herbolozi ili su u njima aktivno učestvovali. Procena je da su herbolozi na naučnim i stručnim skupovima objavili preko 8.000 strana naučnih i stručnih tekstova. Ako se uzme celokupna izdavačka delatnost, uključujući magistarske radove i doktorske disertacije, onda se može reći da su herbolozi, do sada, objavili preko 55.000 strana teksta.

Naučna i stručna aktivnost u oblasti herbologije odvijala se i prezentovanjem rezultata herboloških istrašivanja na drugim naučnim i drugim skupovima u zemlji i inostranstvu koje su organizovali Društvo za zaštitu bilja Srbije i druga društva i organizacije (savetovanjima o pesticidima, kongresima, simpozijumima i savetovanjima zaštite bilja, biološkim i ekološkim naučnim naučnim skupovima).

Naučna i stručna aktivnost u oblasti herbologije karakteriše se velikom raznovrsnošću i aktuelnošću. Sublimirajući manje-više celokupnu delatnost, prezentovanu u naučnim i stručnim časopisima, pre svega u časopisu Acta herbologica, kao i u saopštenjima na kogresima, simpozijumima i savetovanjima, može se konstatovati da su sledeći problemi bili u žiži interesovanja:

- Proučavanje korovske flore i korovskih zajednica u raznim ratarskim i povrtarskim usevima, u voćarskim zasadima i na nepoljoprivrednim površinama; 
- Efikasnost herbicida u suzbijanju korova u različitim usevima, klimatskim i zemljišnim uslovima;

- Delovanje herbicida na gajene i korovske biljke, kao i promene korovske flore i vegetacije;

- Proučavanje razmnožavanja korova, naročito regeneracionih sposobnosti podzemnih vegetativnih organa višegodišnjih korovskih biljaka;

- Proučavanje ekofizioloških karakteristika korovskih biljaka, a pre svega vodnog režima (hidratura, intenzitet transpiracije i dr.) i fotosintetskog režima, kao najvažnijih parametara vezanih za organsku produkciju (sve to i u funkciji primene herbicida ili mera gajenja kulturnih biljaka);

- Proučavanje međusobnih uticaja između korovskih biljaka, kao i korovskih i gajenih biljaka (inter i intraspecijska kompeticija, alelopatija) i

- Pručavanje rezistentnosti korovskih biljaka na herbicide.

\section{Naučni projekti}

Plodan naučno-istraživački rad, od zasnivanja ove naučne i nastavne discipline do danas, krunisan je izradom većeg broja naučnih projekata u kojima su učestvovali naši herbolozi. U ovom pregledu navodimo osnovne projekte, koji su imali istraživački karakter i koji su finansirani od ministarstava naših Vlada, kao i inostrane projekte, koje su finansirale različite međunarodne organizacije ili države. $U$ dosadašnjem periodu naši naučni radnici realizovali su oko 58 projekata, koji su imali istraživački karakter i koji su imali veliki uticaj na razvoj ove oblasti nauke. Navedeni projekti, po pravilu, sadrže naziv projekta, period realizacije/ trajanja, naziv finansijera projekta i rukovodioca projekta.

1. Utvrđivanje štetnog dejstva ostataka hemijskih sredstava u biljnim delovima i zemljištu. 1961-1965. Savezni fond za naučni rad i Republički fond za naučni rad. Rukovodilac projekta prof. dr Radojica Kljajić.

2. Proučavanje anatomsko-histoloških i nekih fizioloških promena kukuruza i soje u zavisnosti od primene različitih pesticida. 1961-1965. Savezni fond za naučni rad i Republički fond za naučni rad. Rukovodilac projekta prof. dr Radojica Kljajić.

3. Proučavanje fizioloških $i$ anatomskih promena koje nastaju na gajenim biljkama posle tretiranja različitim pesticidima (fungicidi, insekticidi i herbicidi). 1964-1967. Savezni fond za naučni rad. Rukovodilac projekta prof. dr Radojica Kljajić.

4. Unapređenje proizvodnje ranog povrća i povrća za industrijsku preradu. Tema: Proučavanje mogućnosti uništavanja korova u krompiru raznim herbicidima. 19661970. Savezni fond za finansiranje naučnih delatnosti. Rukovodilac projekta prof. dr Radojica Kljajić.

5. The Fate and Effect of Herbicide in vegetable crops. 1967-1972. United States of America, Deparment of Agriculture. Rukovodilac projekta prof. dr Vaskrsija Janjić.

6. Proučavanje problema kontaminacije spoljne sredine (vazduh, voda, zemljište i živi organizmi) pesticidima. 1969-1971. Savezni fond za finansiranje naučnih delatnosti. Rukovodilac projekta prof. dr Radojica Kljajić. 
7. Proučavanje problema racionalne primene pesticida. 1970-1975. Republička zajednica za naučni rad Srbije. Rukovodilac projekta prof. dr Radojica Kljajić.

8. Effect of sulphur dioxide on plant phosphorus metabolism. 1972-1976. IAEA. Rukovodilac projekta dr Marijana Plesničar.

9. Problemi proizvodnje i racionalne primene pesticida. 1976. Republička zajednica za naučni rad Srbije.Rukovodilac projekta prof. dr Radojica Kljajić.

10. Isotopic trancer- aided studies of atmospheric sulphur pollutant-plant interaction. 1974-1977. IAEA. Rukovodilac projekta dr Marijana Plesničar.

11. Zaštita bilja. 1976-1980. Republička zajednica nauke Srbije. Rukovodilac projekta dr Mitar Jordović.

12. Uticaj spoljašnjih činioca na bioenergetske procese biljaka. 1976-1980. Republička zajednica nauke Srbije. Rukovodilac projekta dr Marjana Plesničar.

13. The tracer-aided studies on the fate and effect of sulphur dioxide in Spinacea oleracea L. and Triticum vulgare L. 1978-1981. FAO i IAEA. Rukovodilac projekta dr Marijana Plesničar.

14. Kontola korova na površinama solane Bajo Sekulić, Ulcinj. Solana Bajo Sekulić, Ulcinj. 1976-1978. Rukovodilac projekta prof. dr Vaskrsija Janjić.

15. Zagađivanje i dekontaminacija zemljišta. 1981-1985. Republička zajednica nauke Srbije. Rukovodilac projekta dr Đorđe Krnjajić.

16. Proučavanje sastava i mehanizma delovanja preparata Agrostemina. 1981-1983. Bioprodukt, Beograd. Rukovodilac projekta prof. dr Vaskrsija Janjić.

17. Fiziološka i biohemijska ispitivanja biljaka i gljiva u laboratorijskim i prirodnim uslovima. 1981-1985. Republička zajednica nauke Srbije. Rukovodilac projekta prof. dr Mirjana Nešković.

18. Complex examination of herbicides in maize, sunflower and soybean. 1981-1987. United States of America, Department of Agiculture. Rukovodilac projekta prof. dr Vaskrsija Janjić.

19. Zaštita bilja. 1981-1985. Republička zajednica nauke Srbije. Rukovodilac projekta dr Marko Injac.

20. Kontrola korova na površinama tvrđave Herceg Novog. 1982. Opština Herceg Novi. Rukovodilac projekta dr Milka Budimir.

21. Kontrola korova na kanalima i obala utvrdama reka Save i Dunava. 1982-1984 Vodoprivredna organizacija Sava, Beograd. Rukovodilac projekta prof. dr Vaskrsija Janjić.

22. Istraživanje i kontrola korova u sistemu Đerdap. 1984-1986. Vodoprivredna organizacija Dunav-Morava, Požarevac. Rukovodilac projekta prof. dr Vaskrsija Janjić.

23. Totalno uništavanje vegetacije herbicidima na Stojkovoj adi na Dunavu radi podizanja rudnika uglja. 1986-1987. Elektoprivreda Vojvodine. Rukovodilac projekta prof. dr Vaskrsija Janjić.

24. Zaštita bilja. 1986-1990. Ministarstvo nauke Republike Srbije. Rukovodilac projekta dr Borislav Borić. 
25. Zaštita useva od bolesti, štetočina i korova u agroekološkim uslovima PK Beograd. 1989-1990. Osnovna zajednica nauke Beograda. Rukovodilac projekta dr Ilija Perić.

26. Razvoj novih tehnologija zaštite bilja u cilju proizvodnje zdrave hrane. 19911993. Ministarstvo za nauku i tehnološki razvoj Republike Srbije. Rukovodilac projekta prof. dr Milorad Šestović.

27. Razvoj novih tehnologija u suzbijanju biljnih bolesti, štetočina i korova. 19941997. Ministarstvo za nauku i tehnološki razvoj Republike Srbije. Rukovodilac projekta prof. dr Mirko Ivanović.

28. Iznalaženje racionalnih agrotehničkih i tehnoloških rešenja za ublažavanje posledica suše. 1994-1997. Ministarstvo za nauku i tehnološki razvoj Republike Srbije. Rukovodilac projekta dr Slavoljub Milijić.

29. Agrobiološka, biohemijska i ekofiziološka istraživanja u ratarstvu, povrtarstvu, voćarstvu i vinogradarstvu. 1996-1999. Ministarstvo za nauku i tehnologiju Republike Srbije. Rukovodilac projekta prof. dr Vaskrsija Janjić.

30. Ekstrakcija, ispitivanje i proizvodnja prirodnog insekticida iz buhača (Pytethrum cinerariaefolium). 1997-1999. HI Župa, Kruševac. Rukovodilac projekta prof. dr Vaskrsija Janjić.

31. Primena novih biotehnologija i metoda u zaštiti bilja. 1998-2000. Ministarstvo za nauku i tehnološki razvoj Republike Srbije. Rukovodilac projekta dr Miloš Vidić.

32. Istraživanje u zaštiti bilja i primeni pesticida. 2002-2004. Ministarstvo za nauku i tehnološki razvoj Republike Srbije. Rukovodilac projekta prof. dr Vaskrsija Janjić.

33. Monitoring i kontrola ambrozije na teritoriji grada Beograda. 2004-2006. Grad Beograd, Sekretarijat za zaštitu životne sredine. Rukovodilac projekta akademik prof. dr Vaskrsija Janjić.

34. Kartiranje karantinskih, invazivnih i ekonomski štetnih korova na području Srbije sa predlogom mera njihovog suzbijanja. 2004-2007. Ministarstvo poljoprivrede, šumarstva i vodoprivrede Republike Srbije. Rukovodilac projekta prof. dr Sava Vrbničanin.

35. Istraživanja u cilju razvoja novih i poboljšanja postojećih formulacija herbicida.2005-2007. Ministarstvo za nauku i tehnološki razvoj Republike Srbije. Rukovodilac projekta prof. dr Vaskrsija Janjić.

36. Proučavanje pojave i širenje rezistentnih vrsta korova na herbicide $u$ cilju pronalaženja najefikasnije mera suzibjanja. 2005-2008. Ministarstvo za nauku i tehnološki razvoj Republike Srbije. Rukovodilac projekta prof. dr Branko Konstantinović.

37. Weed Flora and Vegetation of Arable Land and Changes in Agroecosystems. 20062007. Projekat Bilateralne saradnje izmerđu R. Srbije i R. Slovenije. Rukovodilac projekta prof. dr Sava Vrbničanin. 
38. Synchronization and Application of Methods for Detection of Weed Species Resistant to Herbicides. 2006-2007. Projekat Bilateralne saradnje između R. Srbije i R. Slovenije. Rukovodilac projekta prof. dr Sava Vrbničanin.

39. Toksični elementi i pesticidi u poljoprivrednom zemljištu i biljnim proizvodima na teritoriji grada Beograda, 2006-2009. Grad Beograd, Sekretarijat za zaštitu životne sredine. Rukovodilac projekta akademik prof. dr Vaskrsija Janjić.

40. Indentifikacija i monitoring alohtonih invazivnih korova (AIK) na području Srbije sa predlogom mera suzbijanja. 2007-2009. Ministarstvo poljoprivrede, šumarstva i vodoprivrede Republike Srbije. Rukovodilac projekta prof. dr Sava Vrbničanin.

41. Pružanje usluga stručnog nadzora za suzbijanje ambrozije na teritoriji Republike Srbije. 2008 -2009. Rukovodilac projekta prof. dr Branko Konstantinović.

42. Kartiranje terena pod ambrozijom na teritoriji AP Vojvodina, 2008. Pokrajinski sekretarijat za zaštitu životne sredine i održivi razvoj. Rukovodilac projekta prof. dr Branko Konstantinović.

43. Razvoj proizvoda i metoda zaštite od štetnih agenasa u cilju održive upotrebe pesticida i zaštite životne sredine. 2008-2010. Ministarstvo za nauku i tehnološki razvoj Republike Srbije. Rukovodilac projekta prof. dr Branko Konstantinović.

44. Biološka, hemijska, toksikološka i ekotoksikološka proučavanja herbicida i njihova primena. 2008-2011. Ministarstvo za nauku i tehnološki razvoj Republike Srbije, Rukovodilac projekta prof. dr Vaskrsija Janjić.

45. Soil Tillage Systems and Fertilization in Crop Production. 2008-2010. Projekat Bilateralne saradnje između R. Srbije i R. Hrvatske. Rukovodilac projekta dr Milena Simić.

46. Monitoring and Managing Herbicide Resistance in Weeds. 2009-2010. Projekat Bilateralne saradnje između R. Srbije i SR Nemačke. Rukovodilac projekta prof. dr Sava Vrbničanin.

47. Monitoring i kontrola ambrozije na teritoriji opštine Obrenovac. 2010-2011. Opština Obrenovac, Fond za razvoj. Rukovodilac projekta akademik prof. dr Vaskrsija Janjić.

48. Monitoring upravljanja otpadom ambalaže za pesticide. 2010. Pokrajinski sekretarijat za zaštitu životne sredine i održivi razvoj. Rukovodilac projekta prof. dr Branko Konstantinović.

49. Unapređenje upravljanja ambalažom za pesticide, 2011-2012. Fond za zaštitu životne sredine Republike Srbije. Rukovodilac projekta prof. dr Branko Konstantinović.

50. Razvoj integrisanih sistema upravljanja štetnim organizmima u biljnoj proizvodnji sa ciljem prevazilaženja rezistentnosti i unapređenja kvaliteta i bezbednosti hrane (potprojekat: Razvoj integrisanih sistema upravljanja korovima u funkciji efikasnosti i prevazilaženja rezistentnosti na herbicide). 2011-2015. Ministarstvo prosvete, nauke i tehnološkog razvoja Republike Srbije. Rukovodilac projekta prof. dr Aleksa Obradović, rukovodilac potprojekta prof. dr Sava Vrbničanin.

51. Proučavanje biljnih patogena, artropoda, korova i pesticida u cilju razvoja metoda bioracionalne zaštite bilja i proizvodnje bezbedne hrane (potprojekat: Proučavanje 
korovskih biljaka i bioloških, hemijskih i toksikoloških osobina hertbicida). 2011-2015. Ministarstvo prosvete, nauke i tehnološkog razvoja Republike Srbije. Rukovodilac projekta dr Dejan Marčić, rukovodilac potprojekta dr Ljiljana Radivojević.

52. Razrada integrisanog upravljanja i primene savremenih principa suzbijanja štetnih organizama u zaštiti bilja (potprojekat: Novi principi u suzbijanju štetnih organizama). 2011-2015. Ministarstvo prosvete, nauke i tehnološkog razvoja Republike Srbije. Rukovodilac projekta dr Veljko Gavrilović, rukovodilac potprojekta dr Danijela Pavlović.

53. International Joint Master Degree in Plant Medicine (IPM). 2011-2013. EU TEMPUS IV projekat. Koordinatori projekta sa srpske strane prof. dr Olivera Petrović-Obradović i doc. dr Aleksandra Ćupina.

54. Sustainable management of Ambrosia artemisiifolia in Europe (SMARTER). 20132016. EU COST Action FA1203. CM koordinatori sa srpske strane prof. dr Sava Vrbničanin i dr Branko Šikoparija.

55. Advancing Research in Agricultural and Food Sciences at Faculty of Agriculture, University of Belgrade - AREA (Research group: Weed Science). 2013-2016. EU FP7REGPOT Project. Rukovodilac projekta prof. dr Radmila Stikić, rukovodilac istraživačke grupe za proučavanje korova prof. dr Sava Vrbničanin.

56. Control and supervision of ragweed treatments services - IPA HUSRB 1002/122/195. EKOVOJVODINA-05. Rukovodilac dr Bojan Konstantinović.

\section{Magistarski radovi}

Intenzivna istraživanja u oblasti herbologije doprinela su razvoju kadrova. Tako je, od 1965. godine do danas, u ovoj oblasti magistriraralo 98, a doktoriralo 74 saradnika. Kao što se iz ovog pregleda vidi, prvi je magistrirao Vasilije Štrbac (1965), a prvi doktor Živko Slavnić je doktorirao u Beču 1944. godine.

1. Vasilije Štrbac (1965). Pručavanje nekih fizioloških i biohemijskih promena biljaka soje (Glycine hispida) u zavisnosti od uticaja nekih pesticida. Univerzitet u Beogradu Poljoprivredni fakultet, Beograd.

2. Marijana Plesničar (1968). Kompleksna jedinjenja adenozin fosfornih kiselina sa jonima gvožđa i kalcijuma. Univerzitet u Beogradu, Prirodno-matematički fakultet, Beograd.

3. Blanka Šajinović (1969). Ekološko - fitocenološka studija ruderalne vegetacije okoline Novog Sada. Univerzitet u Beogradu, Biološki fakultet, Beograd.

4. Sreten Stamenković (1969). Udeo herbicida kao komponenata procesa savremene ptoizvodnje graška namenjenog konzervnoj industriji. Univerzitet u Novom Sadu, Poljoprivredni fakultet, Novi Sad.

5. Vaskrsija Janjić (1970). Prilog proučavanju uticaja alfa - hlor - N,N - dialil - acetamida (CDAA) i izoppropil - (3 - hlor - fenil) karbamata (CIPC) na hemijski sastav graška 
(Pisum sativum L.) u fazi klijanja i kod tehnološke zrelosti. Univerzitet u Beogradu, Poljoprivredni fakultet, Beograd.

6. Ibrahim Elezović (1971). Mogućnost određivanja insekticida iz grupe hlorovanih ugljovodonika u biljnom materijalu fotomigracionom biotest metodom pomoću larvi Aedes aegypti. Univerzitet u Beogradu, Poljoprivredni fakultet, Beograd.

7. Mileta Živanović (1971). Prilog proučavanju hemijskog suzbijanja korova u vinogradima. Univerzitet u Beogradu, Poljoprivredni fakultet, Beograd.

8. Franja Bača (1971). Fitofarmakološka vrednost savremenih sintetičkih herbicida za dominantne vrste korova u kulturi šećerne repe u Vojvodini. Univerzitet u Novom Sadu, Poljoprivredni fakultet, Novi Sad.

9. Mustafa Ali Sultan (1971). Fitofarmakološka vrednost savremenih sintetičkih herbicida na dominantne vrste korova u kulturi kukuruza u severnoj Bačkoj. Univerzitet u Novom Sadu, Poljoprivredni fakultet, Novi Sad.

10. Mladen Marković (1971). Udeo herbicida kao komponente savremenog procesa proizvodnje suncokreta. Univerzitet u Novom Sadu, Poljoprivredni fakultet, Novi Sad.

11. Milka Budimir (1972). Delovanje herbicida CDAA i CIPC na disanje korena graška. Univerzitet u Beogradu, Poljoprivredni fakultet, Beograd.

12. Josip Jaramazović (1972). Uticaj vlažnosti zemljišta na migraciju herbicida amiben i linuron. Univerzitet u Beogradu, Poljoprivredni fakultet, Beograd.

13. Taško Kostov (1973). Efikasnost herbicida trifluralina i hlorambena u suzbijanju korova i njihov uticaj na kvalitet plodova paprike. Univerzitet u Beogradu, Poljoprivredni fakultet, Beograd.

14. Nikola Živković (1973). Prilog proučavanju mogućnosti hemijskog suzbijanja korova u zasadima pitome nane. Univerzitet u Beogradu, Poljoprivredni fakultet, Beograd.

15. Ivan Šilješ (1974). Utvrđivanje efikasnosti i količine ostataka najčešće korišćenih herbicida u kukuruzu na IPL Osijek. Univerzitet u Beogradu, Poljoprivredni fakultet, Beograd.

16. Vesna Martinović (1975). Delovanje atrazina na Hill-ovu reakciju u hloroplastima pšenice i njegovo usvajanje i lokalizacija. Univerzitet u Beogradu, Poljoprivredni fakultet, Beograd.

17. Danica Dražić (1976). Osnovne autoekološke i biljnogeografske karakteristike korovskih biljaka u Bačkoj. Univerzitet u Novom Sadu, Prirodno-matematički fakultet, Novi Sad.

18. Zaim Elezović (1976). Prilog proučavanju mogućnosti hemijskog suzbijanja korova u šečernoj repi. Univerzitet u Beogradu, Poljoprivredni fakultet, Beograd.

19. Blanka Koljadžinski (1976). Uticaj agrotehnike na floristički sastav i neke druge osobine korovske sinuzije u pšenici i kukuruzu. Univerzitet u Novom Sadu, Prirodnomatematički fakultet, Novi Sad.

20. Slavica Bauk (1976). Delovanje simazina na intezitet disanja pšenice. Univerzitet u Beogradu, Poljoprivredni fakultet, Beograd. 
21. Stana Erdevik- Graovac (1977). Uporedna vrednost nekih herbicida selektivnih za soju s posebnim osvrtom na sastav spontane flore u ovoj kulturi u Sremu. Univerzitet u Novom Sadu, Poljoprivredni fakultet, Novi Sad.

22. Ana Labat (1977). Uporedna vrednost antigraminarnih herbicida selektivnih za kukuruz i udeo uskolisnih korova u spontanoj flori u ovoj kulturi. Univerzitet u Novom Sadu, Poljoprivredni fakultet, Novi Sad.

23. Petros Charalambouus (1978). Mogućnost primene kombinacije herbicida i mineralnih đubriva pri hemijskom suzbijanju korova u kukuruzu. Univerzitet u Beogradu, Poljoprivredni fakultet, Beograd.

24. Lidija Miržinski - Stefanović (1978). Proučavanje dejstva atrazina na fotohemijske procese kod biljke kukuruza. Univerzitet u Beogradu, Prirodno-matematički fakultet, Beograd.

25. Marija Arsenović (1978). Mogućnost eliminisanja korovske vegetacije na bankinama i kosinama kanala na hidromelioracionim objektima u Bačkoj uz primenu herbicida. Univerzitet u Novom Sadu, Poljoprivredni fakultet, Novi Sad.

26. Helga Godec (1978). Proučavanje stepena efikasnosti granuliranih herbicidnih đubriva apliciranih u vinogradima i voćnjacima na peščanim terenima severne Bačke. Univerzitet u Novom Sadu, Poljoprivredni fakultet, Novi Sad.

27. Milutin Blagojević (1978). Uticaj različitih formulacija i tehničke aplikacije triazinskih herbicida primenjenih u kulturi kukuruza na stepen njihove efikasnosti i tok degradacije. Univerzitet u Novom Sadu, Poljoprivredni fakultet, Novi Sad.

28. Demrdash Abdelhakem el Sherbeni (1978). Tok degradacije triazinskih herbicida različitih formulacija. Univerzitet u Novom Sadu, Poljoprivredni fakultet, Novi Sad.

29. Milivoje Milivojević (1978). Fitofarmakološka vrednost savremenih herbicida za dominantne vrste korova u kulturi krompira. Univerzitet u Novom Sadu, Poljoprivredni fakultet, Novi Sad.

30. Vladimir Stepanović (1978). Fitofarmakološka vrednost herbicida i herbicidnih đubriva primenjenih u kukuruzu i udeo uskolisnih korova u ovoj kulturi u području Bosanske Posavine. Univerzitet u Novom Sadu, Poljoprivredni fakultet, Novi Sad.

31. Milorad Tešić (1979). Efikasnost i stepen selektivnosti herbicida apliciranih u šećernoj repi u reonu srednjeg Banata sa posebnim osvrtom na uskolisne korove. Univerzitet u Novom Sadu, Poljoprivredni fakultet, Novi Sad.

32. Sofija Pejin (1980). Dostupnost atrazina u različitim tipovima zemljišta i njegovi efekti na gajene biljke. Univerzitet u Beogradu, Poljoprivredni fakultet, Beograd.

33. Branko Konstantinović (1980). Proučavanje mogućnosti suzbijanja emerznih korova na lokalitetima vodoprivrednih organizacija Zrenjanin i Vršac. Univerzitet u Osijeku, Poljoprivredni fakultet, Osijek.

34. Rade Stanković (1980). Proučavanje mogućnosti suzbijanja korova primenom herbicida u zasadima jabuke u gustoj sadnji. Univerzitet u Osijeku, Poljoprivredni fakultet, Osijek. 
35. Živica Radin (1981). Sastav korovske sinuzije u boraniji za konzervnu industriju i mogućnost eliminisanja korova primenom herbicida. Univerzitet u Novom Sadu, Poljoprivredni fakultet, Novi Sad.

36. Radomir Ognjanović (1982). Uporedno ispitivanje pogodnosti savremenih traktorskih prskalica u primeni herbicida u šećernoj repi. Univerzitet u Sarajevu, Poljoprivredni fakultet, Sarajevo.

37. Srbislav Maksimović (1982). Suzbijanje korova herbicidima u kulturi crnog bora na Goču. Univerzitet u Beogradu, Šumarski fakultet, Beograd.

38. Ivan Rudinski (1982). Proučavanje korovske sinuzije u zasadu kajsija na području Ljutova (Subotica) i efekti primene selektivnih herbicida za ovu kulturu. Univerzitet u Osijeku, Poljoprivredni fakultet, Osijek.

39. Petar Kovačević (1983). Proučavanje stepena efikasnosti herbicida za suncokret i njihov uticaj na kvalitativna i kvantitativna svojstva merkantilnog materijala (semena) ove kulture gajene na černozemu telećke zaravni. Univerzitet u Novom Sadu, Poljoprivredni fakultet, Novi Sad.

40. Radmila Stanković - Kalezić (1984). Disanje i sinteza hlorofila u prvim fazama razvića pčenice (Triticum vulgare L.) u prisustvu kukolja. Univerzitet u Beogradu, Prirodnomatematički fakultet, Beograd.

41. Branislav Veljković (1984). Prilog proučavanju hemijskog suzbijanja korova u semenskim travama. Univerzitet u Beogradu, Poljoprivredni fakultet. Beograd.

42. Miloš Pavlović (1984). Sastav korovske sinuzije u kukuruzu na različitim tipovima zemljišta i mogućnost eliminisanja dominantnih korovskih vrsta uz aplikaciju herbicida. Univerzitet u Osijeku, Poljoprivredni fakultet, Osijek.

43. Aleksandar Radovanović (1984). Proučavanje mogućnosti eliminisanja korovske sinuzije primenom herbicida na kanalima Dunav-Tisa-Dunav (Srednji Banat), Zrenjanin. Univerzitet u Osijeku, Poljoprivredni fakultet, Osijek.

44. Miroslav Trifić (1985). Proučavanje korovske sinuzije u suncokretu na različitim tipovima zemljišta u srednjem Banatu kao osnove za izbor herbicida selektivnih za ovu kulturu. Univerzitet u Novom Sadu, Poljoprivredni fakultet, Novi Sad.

45. Otilija Šerkezi (1985). Proučavanje mogućnosti eliminisanja korova u kukuruzu uz aplikaciju manje perzistentnih herbicida u reonu srednje Bačke. Univerzitet u Novom Sadu, Poljoprivredni fakultet, Novi Sad.

46. Milica Mojašević (1986). Prilog uporednom određivanju mikrokoličina herbicida iz grupe triazina, triazinola i dinitroanilina. Univerzitet u Beogradu, Poljoprivredni fakultet, Beograd.

47. Jasenka Fejzo (1986). Proučavanje delovanja kofaktora cikličnog transporta elektrona i fotofosforilacije na indukciju fluorescencije hlorofila u intaktnim hloroplastima. Univerzitet u Beogradu, Prirodno-matematički fakultet, Beograd.

48. Mohamed Omar (1988). Uporedno određivanje fenooksikarbonskih kiselina primenom volumetrijskih i gasnohromatografskih metoda. Univerzitet u Beogradu, Poljoprivredni fakultet, Beograd. 
49. Sonja Veljović (1989). Složena kinetika gašenja fluorescencije hlorofila u toku fotosinteze u intaktnim izolovanim hloroplastima graška (Pisum sativum L.). Univerzitet u Beogradu, Prirodno-matematički fakultet, Beograd.

50. Vera Milošević (1989). Uticaj ekoloških faktora na korovsku vegetaciju kukuruza u nekim područjima severozapadne Srbije. Univerzitet u Beogradu, Poljoprivredni fakultet, Beograd.

51. Radivoje Jevtić (1990). Uticaj predsetvene primene urea i nekih herbicida i insekticida na razvoj šećerne repe. Univerzitet u Novom Sadu, Poljoprivredni fakultet, Novi Sad.

52. Ljubinko Jovanović (1990). Delovanje fluazifop- p- butila na vodni režim kukuruza u uslovima suše i sadržaj abcisinske kiseline. Univerzitet u Beogradu, Poljoprivredni fakultet, Beograd.

53. Sava Ajder (1991). Uticaj nekih herbicida na fitocenološke promene korovske zajednice useva kukuruza. Univerzitet u Beogradu, Poljoprivredni fakultet, Beograd.

54. Mile Ivanović (1992). Proučavanje korovskih zajednica useva pšenice, kukuruza i šećerne repe na različitim tipovima zemljišta u jugozapadnom Banatu. Univerzitet u Beogradu, Poljoprivredni fakultet, Beograd.

55. Hussein Hammoud (1992). Proučavanje uticaja herbicida atrazina, alahlora i EPTC na različite hibride kukuruza. Univerzitet u Beogradu, Poljoprivredni fakultet, Beograd.

56. Maja Vojvodić-Vuković (1992). Uticaj herbicida na brojnost i enzimatsku aktivnost mikroorganizama pod usevom graška. Univerzitet u Novom Sadu, Poljoprivredni fakultet, Novi Sad.

57. Goran Malidža (1995). Reakcija inbred linija kukuruza na primenu herbicida iz grupe sulfonilurea. Univerzitet u Novom Sadu, Poljoprivredni fakultet, Novi Sad.

58. Ljiljana Tamburić (1995). Uticaj herbicida na gljive iz roda Fusarium koje se razvijaju u zemljištu, na korenu i stablu kukuruza (Zea mays L.). Univerzitet u Beogradu, Poljoprivredni fakultet, Beograd.

59. Maja Babović (1995). Korovska vegetacija u usevu pšenice i njeno suzbijanje. Univerzitet u Novom Sadu, Poljoprivredni fakultet, Novi Sad.

60. Miomir Šašlić (1995). Efikasnost herbicida na korove u usevu pšenice. Univerzitet u Novom Sadu, Poljoprivredni fakultet, Novi Sad.

61. Milan Milenković (1995). Proučavanje nekih mogućnosti suzbijanja bele imele (Viscum album L. Fam. Loranthaceae). Univerzitet u Beogradu, Šumarski fakultet, Beograd.

62. Tatjana Sretenović-Rajčić (1996). Reaktivnost različitih genotipova kupusa (Brassica oleracea var. capitata) na delovanje herbicida parakvata. Univerzitet u Beogradu, Biološki fakultet, Beograd.

63. Barbara Nađ-Dorotić (1996). Efikasnost herbicida za suzbijanje korova u soji. Univerzitet u Novom Sadu, Poljoprivredni fakultet, Novi Sad.

64. Ivana Božović (1996). Dejstvo hormonalnih herbicida na kvalitativne osobine pšenice (Triticum aestivum L.). Univerzitet u Novom Sadu, Poljoprivredni fakultet. Novi Sad. 
65. Branka Orbović (1996). Efikasnost i perzistentnost nekih herbicida u soji. Univerzitet u Novom Sadu, Poljoprivredni fakultet, Novi Sad.

66. Mirjana Pucarević (1996). Određivanje rezidua herbicida u vodama zalivnog sistema PIK Bečej, Bečej. Univerzitet u Novom Sadu, Tehnološki fakultet, Novi Sad.

67. Bogdan Nikolić (1997). Uticaj herbicida metribuzina, linurona i dikvata na sadržaj fotosintetskih pigmenata u listu soje (Glycine max Merr.). Univerzitet u Beogradu, Biološki fakultet, Beograd.

68. Tijana Petrović (1997). Parazitska mikroflora korova u usevu kukuruza. Univerzitet u Novom Sadu, Poljoprivredni fakultet. Novi Sad.

69. Ljiljana Radivojević (1998). Uticaj alahlora, metolahlora i metribuzina na zemljišnu mikrofloru. Univerzitet u Beogradu, Poljoprivredni fakultet, Beograd.

70. Ljiljana Šantrić (1999). Uticaj alahlora, linurona i fomesafena na mikrofloru zemljišta pod sojom. Univerzitet u Beogradu, Poljoprivredni fakultet, Beograd.

71. Milena Stanojević (1999). Uticaj gustine useva i primene herbicida na floristički sastav i građu korovske zajednice kukuruza (Zea mays L.). Univerzitet u Beogradu, Poljoprivredni fakultet, Beograd.

72. Vladan Jovanović (1999). Kultura transformisanih korenova heljde (Fagopyrum esculentum Moench) i himalajske skopolije (Scopolia lurida Dunal). Univerzitet u Beogradu, Biološki fakultet, Beograd.

73. Svjetlana Cupać (2000). Karakteristike zemljišta prirodnih staništa buhača (Tanacetum cineraraefolium Trev.) na području Crne Gore. Univerzitet u Beogradu, Poljoprivredni fakultet, Beograd.

74. Mladen Tatić (2000). Uticaj desikacije na prinos i kvalitet semena soje (Glycine max (L.) Merr.). Univerzitet u Novom Sadu, Poljoprivredni fakultet, Novi Sad.

75. Simonida Đurić, (2000). Uticaj herbicida na mikrobiološku aktivnost u zemljištu pod usevom kukuruza, Univerzitet u Novom Sadu, Poljoprivredni fakultet, Novi Sad.

76. Dragana Marisavljević (2001). Ispitivanje osobina buhača (Chrysanthemum cineraraefolium Trev.) sa prirodih staništa Crne Gore u cilju njegovog gajenja. Univerzitet u Beogradu, Poljoprivredni fakultet, Beograd.

77. Katarina Jovanović-Radovanov (2002). Osetljivost hibrida kukuruza (Zea mays L.) na rezidualno delovanje trifluralina i imazetapira. Univerzitet u Beogradu, Poljoprivredni fakultet, Beograd.

78. Marko Nestorović (2002). Ekološko-fitogeografske karakteristike korovske flore urbane sredine u cilju iznalaženja mera borbe. Univerzitet u Novom Sadu, Poljoprivredni fakultet, Novi Sad.

79. Branko Planojević (2003). Korovska vegetacija zasada jabuke i njeno suzbijanje. Univerzitet u Novom Sadu, Poljoprivredni fakultet, Novi Sad.

80. Boris Popović (2004). Oksidativni stres i rezistentnost nekih korova na delovanje atrazina i metalohlora. Univerzitet u Novom Sadu, Poljoprivredni fakultet, Novi Sad.

81. Siniša Mitrić (2004). Proučavanje korova voćnjaka kao osnova za primjenu herbicida. Univerzitet u Banjoj Luci, Poljoprivredni fakultet, Banja Luka. 
82. Maja Meselđžija (2004). Ispitivanje rezistentnosti nekih korovskih vrsta na triazinske herbicide. Univerzitet u Novom Sadu, Poljoprivredni fakultet, Novi Sad.

83. Piljo Dakić (2005). Proučavanje korova u usevu pšenice i kukuruza i mogućnost njihovog suzbijanja primenom herbicida. Univerzitet u Banjoj Luci, Poljoprivredni fakultet, Banja Luka.

84. Dragana Božić (2005). Ispitivanje rezistentnosti biljaka na herbicide ALS-inhibitore. Univerzitet u Beogradu, Poljoprivredni fakultet, Beograd.

85. Slobodanka Marković (2005). Mogućnost primene herbicida u mladom zasadu jabuke. Univerzitet u Beogradu, Poljoprivredni fakultet, Beograd.

86. Danijela Pavlović (2005). Utvrđivanje rezistentnosti korova prema herbicidima inhibitorima fotosinteze. Univerzitet u Beogradu, Poljoprivredni fakultet, Beograd.

87. Divna Marić (2005). Proučavanje rezistentnih vrsta korova na herbicide ALS inhibitore. Univerzitet u Novom Sadu, Poljoprivredni fakultet, Novi Sad.

88. Dragan Mataruga (2006). Proučavanje efikasnosti folijarnih herbicida u suzbijanju ambrozije (Ambrosia artemisifolia L.). Univerzitet u Banjoj Luci, Poljoprivredni fakultet, Banja Luka.

89. Verica Vasić (2006). Proučavanje efikasnosti herbicida u suzbijanju korovske vegetacije u proizvodnji sadnica topola (Populus sp.). Univerzitet u Novom Sadu, Poljoprivredni fakultet, Novi Sad .

90. Bojan Konstantinović (2006). Rasprostranjenost i suzbijanje korovsko-ruderalne alergene biljke Ambrosia artemisiifolia L. u reginu grada Novog Sada Univerzitet u Novom Sadu, Poljoprivredni fakultet. Novi Sad.

91. Dragana Šunjka (2006). Ispitivanje rezistentnosti korovsko-ruderalne biljke Datura stramonium L. na herbicide iz grupe ALS inhibitora. Univerzitet u Novom Sadu, Poljoprivredni fakultet, Novi Sad.

92. Slađana Santrač (2009). Ispitivanje rezistentnosti korovske vrste Ecinochloa crus-gali L. na herbicide iz grupe ALS inhibitora. Univerzitet u Novom Sadu, Poljoprivredni fakultet, Novi Sad.

93. Biljana Vučković (2011). Određivanje sjemena korova u zemljištu kao osnova za izbor zemljišnih herbicida. Univerzitet u Banjoj Luci, Poljoprivredni fakultet, Banja Luka.

94. Žarko Đakić (2011). Suzbijanje ruderalno-korovske vrste Ambrosia artemisiifolia L. primenom herbicida. Univerzitet u Novom Sadu, Poljoprivredni fakultet, Novi Sad

95. Ilija Milijašević (2011). Uticaj različitih metoda suzbijanja korovske vegetacije na rast i razvoj sadnica smrče (Picea abies L.Karst.) u pikirištu. Univerzitet u Beogradu, Šumarski fakultet, Beograd.

96. Tijana Miskin (2013). Korovska flora suncokreta i mogućnosti suzbijanja korova primenom herbicida. Univerzitet u Novom Sadu, Poljoprivredni fakultet, Novi Sad.

97. Milivoj Pavlović (2014). Utrvrđivanje rezistentnosti monokotiledonih korova na triazinske herbicide. Univerzitet u Novom Sadu, Poljoprivredni fakultet, Novi Sad. 
98. Eleonora Onć-Jovanović (2014). Kompetitivna interakcija useva kukuruza i korovske vrste Abutilon theophrasti Medik. Univerzitet u Beogradu, Poljoprivredni fakultet, Beograd.

\section{Doktorske disertacije}

1. Živko Slavnić (1944). Die Unkrautgesellschaften des serbischen Banats. Wien.

2. Momčilo Kojić (1958). Zastupljenost, uloga i značaj đipovine (Chrysopogon grillus Trin.) u livadskim fitocenozama zapadne Srbije. Univerzitet u Beogradu, Poljoprivredni fakultet, Beograd.

3. Milan Čanak (1961). Ekološka studija vodene vegetacije u barama duž Velike Morave. Univerzitet u Beogradu, Prirodno-matematički fakultet, Beograd.

4. Dušan. Milošević (1965). Važnije bioekološke osobine divljeg sirka (Sorghum halepense Pers) i njegova rasprostranjenost u Mačvi. Univerzitet u Beogradu, Poljoprivredni fakultet. Beograd.

5. Zdravko Kosovac (1964). Biološko i rezidualno dejstvo herbicida na bazi triazina i fenoksi sirćetne kiseline na korovsku floru u kukuruzu, na černozemu u južnoj Bačkoj. Univerzitet u Novom Sadu, Poljoprivredni fakultet, Novi Sad.

6. Danica Gajić (1964). Uzajmni odnosi pšenice i kukolja. Univerzitet u Beogradu, Poljoprivredni fakultet. Beograd.

7. Žarko Živanović (1965). Ekologija, varijabilnost, rasprostranjenje i ontogenetsko razviće pirevine (Agropyrum repens Beauv.). Univerzitet u Beogradu, Poljoprivredni fakultet, Beograd.

8. Stojan Čuturilo (1966). Primena hormonskih herbicida u različitim agrosinuzijama strnih žita. Univerzitet u Skoplju, Poljoprivredni fakultet, Skoplje.

9. Milan Panić (1970). Über die aufnahme von 2,4-dihlorophenoxyessigsäure durch bohnen- und weizenblätter in beziehung zum ektodesmenproblem mit besonderer berücksichtigung des ascorbinsäuregehaltes. Inaugural - Dissertation zur Erlangung des Doktorgrades der landwuetschaft (Dr. Agr.) der Hohen Landwirtschaftlichen Fakultät der Rheinischen Friedrich-Wilhelms-Universität zu Bonn. Germany.

10. Vasilije Štrbac (1971). Uticaj herbicida (amiben, NPA, CDAA i CP-31393) na sastav semena i mobilizaciju azota ponika biljaka soje (Glycine hispida Max). Univerzitet u Beogradu, Farmaceutski fakultet, Beograd.

11. Marijana Plesničar (1971). Photochemical activities of barley plastids in different stages of their development. University of Cambridge, England.

12. Borivoj Šinžar (1971). Prilog proučavanju delovanja fungicida za zaprašivanje semena (TMTD i MEMS) na intezitet nekih fizioloških procesa u fazi klijanja i nicanja kukuruza. Univerzitet u Beogradu, Poljoprivredni fakultet, Beograd.

13. Ksenija Mijatović (1971). Ekološka i morfološko-anatomska proučavanja korova Amaranthus blitoides Wats. u Vojvodini, kao osnova za njegovo suzbijanje. Univerzitet u Beogradu, Poljoprivredni fakultet. Beograd. 
14. Miloš Mišović (1972). Ispitivanje dejstva linurona i prometrina u različitim agroekološkim uslovima na organsku produkciju, kvalitet krompira i stepen efikasnosti u suzbijanju krompira. Univerzitet u Beogradu, Poljoprivredni fakultet, Beograd.

15. Bogdan Svrkota (1973). Contibution al' etude de'l action de'certains herbicides (aminotriazines et acide dichlorophenoxyacetique). Univeresite D 'Orleans U.E.R. Du Centre D'Etudes Superieures Ligeriennnes, Department De Physiologie Vegetable. Paris, France.

16. Vaskrsija Janjić (1975). Prilog proučavanju azotnih jedinjenja graška za vreme heterotrofne ishrane i promena izazvanih herbicidom CIPC. Univerzitet u Beogradu, Poljoprivredni fakultet, Beograd.

17. Aleksandar Laban (1975). Ekološko-fitocenološka proučavanja korova u plantažnim voćnjacima SAP Kosovo kao osnova za iznalaženje najracionalnih mera suzbijanja. Univerzitet u Beogradu, Poljoprivredni fakultet. Beograd.

18. Mileta Živanović (1976). Proučavanje mogućnosti primene aminotriazina i parakvata za suzbijanje korova u vinogradima. Univerzitet u Beogradu, Poljoprivredni fakultet. Beograd.

19. Branislav Nikolić (1976). Kvalitativne i kvantitativne promene lucerke kao posledica aplikacije herbicida namenjenih suzbijanju korova u ovoj kulturi. Univerzitet u Novom Sadu, Poljoprivredni fakultet, Novi Sad.

20. Georgije Gojković (1977). Farmakološka vrednost selektivnih herbicida u rasadnicima topole (Populus euramericana Guinier C1-I-214) na aluvijumu reke Dunav. Univerzitet u Novom Sadu, Poljoprivredni fakultet, Novi Sad.

21. Mladen Marković (1977). Uticaj herbicida na ozime sorte pšenice u zavisnosti od faze razvoja. Univerzitet u Novom Sadu, Poljoprivredni fakultet, Novi Sad.

22. Slavoljub Milijić (1979). Korovska vegetacija ozime pšenice Timočke krajine. Univerzitet u Skoplju, Poljoprivredni fakultet, Skoplje.

23. Milka Budimir (1979). Usvajanje, translokacija i delovanje linurona i monolinurona u grašku. Univerzitet u Beogradu, Poljoprivredni fakultet, Beograd.

24. Sherbeni Abd Ei - Hakem (1982). Proučavanje stepena slobode izbora kultura na površinama tretiranih prethodne godine herbicidima selektivnim za kukuruz. Univerzitet u Novom Sadu, Poljoprivredni fakultet, Novi Sad.

25. Danica Dražić (1983). Uticaj divljeg sirka (Sorghum halepense Pers.) na prinos i kvalitet zrna kukuruza. Univerzitet u Novom Sadu, Poljoprivredni fakultet, Novi Sad.

26. Marija Arsenović (1984). Proučavanje mogućnosti eliminisanja korova u kanalima Dunav-Tisa-Dunav u južnoj Bačkoj. Univerzitet u Osijeku, Poljoprivredni fakultet, Osijek.

27. Branko Konstatinović (1984). Proučavanje mogućnosti suzbijanja emerznih vrsta korova u kanalima Dunav-Tisa-Dunav uz osvrt na kombinaciju vode i zemlje. Univerzitet u Osijeku, Poljoprivredni fakultet, Osijek.

28. Lidija Stefanović (1984). Korovska vegetacija kukuruza severoistočne Srbije. Univerzitet u Beogradu, Poljoprivredni fakultet, Beograd. 
29. Radenko Stepić (1984). Korovska vegetacija strnih žita u severnozapadnoj Srbiji. Univerzitet u Beogradu, Poljoprivredni fakultet, Beograd.

30. Jan Časar (1984). Biološke osnove zaštite šećerne repe od korova. Univerzitet u Novom Sadu, Poljoprivredni fakultet, Novi Sad.

31. Ibrahim Elezović (1985). Proučavanje stepena i obima zagađenosti voda SR Srbije postojanim pesticidima. Univerzitet u Beogradu, Poljoprivredni fakultet, Beograd.

32. Vladimir Stepanović (1985). Biološke osnove suzbijanja korova u pšenici aplikacijom herbicida u rastvoru mineralnih đubriva. Univerzitet u Novom Sadu, Poljoprivredni fakultet, Novi Sad.

33. Mladen Baćanović (1986). Uticaj populacije dominantnih korovskih vrsta u Mačvi na kvantitativne osobine soje. Univerzitet u Novom Sadu, Poljoprivredni fakultet, Novi Sad.

34. Branislav Veljković (1987). Fitofarmakološke karakteristike herbicida fluatifop-p- butil i haloksifop-etoksietil. Univerzitet u Novom Sadu, Poljoprivredni fakultet, Novi Sad.

35. Rade Stanković (1987). Proučavanje korovske vegetacije zasada jabuke u cilju iznalaženja racionalnih mera primene herbicida. Univerzitet u Osijeku, Poljoprivredni fakultet, Osijek.

36. Helga Godec (1988). Proučavanje selektivnosti i perzistentnosti herbicida u šećernoj repi uz verifikaciju slobode izbora narednih kultura. Univerzitet u Novom Sadu, Poljoprivredni fakultet, Novi Sad.

37. Slavko Crnčević (1988). Karakteristike korovske vegetacije voćnjaka Srema sa posebnim osvrtom na uticaj ekoloških faktora. Univerzitet u Novom Sadu, Prirodnomatematički fakultet, Novi Sad.

38. Radomir Ognjanović (1988). Uticaj načina primene, doze mineralnih đubriva i načina obrade zemljišta na strukturu i dinamiku korovske sinuzije u pšenici i kukuruzu. Univerzitet u Sarajevu, Poljoprivredni fakultet, Sarajevo.

39. Milorad Tešić (1989). Osnove zaštite kukuruza od korova u srednjem Banatu. Univerzitet u Novom Sadu, Poljoprivredni fakultet, Novi Sad.

40. Milica Mojašević (1990). Pokretljivost insekticida i herbicida u zemljištu. Univerzitet u Beogradu, Poljoprivredni fakultet, Beograd.

41. Đorđe Barać (1992). Proučavanje toka degradacije herbicida selektivnih za šećernu repu. Univerzitet u Novom Sadu, Poljoprivredni fakultet, Novi Sad.

42. Dušan Jovanović (1994). Delovanje herbicida na korove u zasadima jagoda. Univerzitet u Novom Sadu, Poljoprivredni fakultet, Novi Sad.

43. Sava Ajder (1996). Fitocenološke i ekofiziološke promene korovske vegetacije strnih žita u zavisnosti od visinskog gradijenta. Univerzitet u Beogradu, Poljoprivredni fakultet, Beograd.

44. Ljubinko Jovanović (1997). Transport i distribucija abcisinske kiseline (ABA) u korenu linija kukuruza (Zea mays L.). Univerzitet u Beogradu, Poljoprivredni fakultet, Beograd. 
45. Mile Ivanović (2000). Građa i promena korovske zajednice okopavina u uslovima intenzivne primene herbicida u jugozapadnom Banatu. Univerzitet u Novom Sadu, Poljoprivredni fakultet, Novi Sad.

46. Zoran Jovović (2001). Uticaj načina suzbijanja korova na prinos sjemenskog usjeva različitih sorata krompira. Univerzitet u Beogradu, Poljoprivredni fakultet, Beograd.

47. Radivoje Đurđević (2001). Uticaj herbicida na korove i biološka svojstva samooplodnih linija kukuruza (Zea myas L.). Univerzitet u Novom Sadu, Poljoprivredni fakultet, Novi Sad.

48. Milivoje Milivojević, (2001). Uticaj herbicida na korove i biološka svojstva samooplodnih linija kukuruza (Zea mays L.). Univerzitet u Novom Sadu, Poljoprivredni fakultet, Novi Sad.

49. Branislav Knežević (2001). Genotipske razlike pšenice izazvane nekim herbicidima u zavisnosti od fenofaze tretiranja. Univerzitet u Prištini, Poljoprivredni fakultet, Kruševac.

50. Maja Babović-Đorđević (2002). Uticaj kasnog roka primene herbicida na morfološke karakteristike genotipova ozime pšenice (Triticum aestivium L.) i korovsku sinuziju. Univerzitet u Prištini. Poljoprivredni fakultet, Kruševac.

51. Milena Simić (2003). Sezonska dinamika korovske sinuzije, kompetitivnost i produktivnost kukuruza u integralnim sistemima kontrole zakorovljenosti. Univerzitet u Beogradu, Poljoprivredni fakultet, Beograd.

52. Snežana Živanović-Katić (2004). Uticaj kalcizacije na floristički sastav korovske zajednice i prinos strnih žita. Univerzitet u Beogradu, Poljoprivredni fakultet, Beograd.

53. Ljiljana Radivojević (2006). Delovanje atrazina i nikosulfurona na mikroorganizme u zemljištu. Univerzitet u Beogradu, Poljoprivredni fakultet, Beograd.

54. Radmila Stanković-Kalezić (2007). Sinekološka i floristička studija ruderalne vegetacije na području Pančevačkog rita. Univerzitet u Beogradu, Poljoprivredni fakultet, Beograd.

55. Dragana Marisavljević (2007). Rasprostranjenost, biološke karakteristike i suzbijanje ive (Iva xanthifolia Nutt.). Univerzitet u Novom Sadu, Poljoprivredni fakultet, Novi Sad.

56. Bogdan Nikolić (2007). Inhibicija fotosinteze i rastenja kukuruza (Zea mays L.) u uslovima stresa izazvanim herbicidom sulfosat. Univerzitet u Kragujevcu, Prirodnomatematički fakultet, Kragujevac.

57. Vesna Dragičević (2007). Uticaj ubrzanog starenja i stimulativnih koncentracija 2,4-D na seme kukuruza (Zea mays L.). Univerzitet u Novom Sadu, Poljoprivredni fakultet, Novi Sad.

58. Vera Milošević (2008). Ekološka i fitogeografska analiza korovske flore okopavina u Mačvi. Univerzitet u Novom Sadu, Poljoprivredni fakultet, Novi Sad.

59. Goran Malidža (2008). Selektivnost sulfonilurea herbicida prema kukuruzu u zavisnosti od genotipa i primene zemljišnih insekticida. Univerzitet u Beogradu, Poljoprivredni fakultet, Beograd. 
60. Marko Nestorović (2008). Procena biodiverziteta korovske flore urbanih sredina. Univerzitet u Novom Sadu, Poljoprivredni fakultet, Novi Sad.

61. Maja Meseldžija (2009). Ispitivanje rezistentnosti korovskih vrsta na herbicide iz grupe inhibitora acetolaktat sintetaze. Univerzitet u Novom Sadu, Poljoprivredni fakultet, Novi Sad.

62. Vladan Jovanović (2009). Interakcija temperature, svetlosti i azotnih jedinjenja u klijanju semena mišjakinje (Stellaria media L. (Vill). Univerzitet u Beogradu, Biološki fakultet, Beograd

63. Snežana Jarić (2009). Alohtone biljne vrste u prirodnim i antropogeno izmenjenim fitocenozama Srema. Univerzitet u Beogradu, Poljoprivredni fakultet, Beograd.

64. Danijela Pavlović (2010). Osetljivost biljaka na glifosat: morfo-anatomski, fiziološki i biohemijski aspekt. Univerzitet u Beogradu, Poljoprivredni fakultet, Beograd.

65. Simonida Đurić (2010). Mikroorganizmi u zemljištu pod usevom kukuruza i njihov potencijal za razgradnju sulfonilurea herbicida. Univerzitet u Novom Sadu, Poljoprivredni fakultet, Novi Sad.

66. Siniša Mitrić (2011). Proučavanje biološke aktivnosti, mobilnosti i perzistentnosti imazetapira u zemljištu. Univerzitet u Banjoj Luci, Poljoprivredni fakultet, Banja Luka.

67. Dragana Božić (2011). Reakcije korovskih populacija i hibrida suncokreta prema herbicidima inhibitorima acetolaktat sintetaze. Univerzitet u Beogradu, Poljoprivredni fakultet, Beograd.

68. Verica Vasić (2012). Efikasnost i selektivnost herbicida u obnovljenim šumama hrasta lužnjaka. Univerzitet u Novom Sadu, Poljoprivredni fakultet, Novi Sad.

69. Olivera Ilić (2012). Efekat različitih agrotehničkih mera u proizvodnji krompira na sastav korovske flore. Univerzitet u Novom Sadu, Poljoprivredni fakultet, Novi Sad.

70. Katarina Jovanović-Radovanov (2012). Osetljivost gajenih biljaka na rezidualno delovanje imazetapira i klomazona. Univerzitet u Beogradu, Poljoprivredni fakultet, Beograd.

71. Divna Marić (2013). Utvrđivanje rezistentnosti korovskih vrsta Datura stramonium L. i Xanthium strumarium L. na herbicide ALS inhibitore. Univerzitet u Novom Sadu, Poljoprivredni fakultet, Novi Sad.

72. Bojan Konstatinović (2013). Ambrosia artemisiifolia L. - rezerve semena u zemljištu, klijavost, rasprostranjenost i suzbijanje. Univerzitet u Novom Sadu, Poljoprivredni fakultet, Novi Sad.

73. Ljiljana Šantrić (2013). Promene mikrobiološke aktivnosti zemljišta nakon primene herbicida. Univerzitet u Novom Sadu, Poljoprivredni fakultet, Novi Sad.

74. Marija Sarić-Krsmanović (2013). Biologija viline kosice (Cuscuta campestris Yunk.) i mogućnost njenog suzbijanja. Univerzitet u Beogradu, Poljoprivredni fakultet, Beograd. 


\section{Izdavačka delatnost u oblasti herbologije (monografije, knjige, udžbenici i priručnici)}

Plodan naučno-istraživački rad, kao i stručna aktivnost, koji su ispoljeni poslednjih pedesetak godina, od zasnivanja ove naučno-stručne i nastavne discipline do danas, krunisan je izradom i publikovanjem većeg broja monografija, knjiga, udžbenika i priručnika o korovima, herbicidima i drugim aspektima herbološke problematike. Prema našoj prikupljenoj građi, u dosadašnjem periodu objavljeno je oko 118 različitih publikacija iz ove oblasti na preko 30.000 stranica. U ovom pregledu dajemo podatke o izdanjima naučnih i stručnih radnika koji se bave ili su se bavili herbologijom.

1. Anđelić, R., Mladenović, LJ., Otašević R. (1973). Korovi i njihovo suzbijanje herbicidima. Mala poljoprivredna biblioteka, 1-64, Beograd.

2. Arsić, M., Vojvodić, Đ. (1960). O suzbijanju korova hemijskim sredstvima - herbicidima. Zadružna knjiga,1-30, Beograd.

3. Crnčević S. (1994). Korovska vegetacija voćnjaka Fruške gore. Matica srpska,1-86, Novi Sad.

4. Čamprag, D., Marić, A. (ur.) (2002). Bolesti, štetočine i korovi kukuruza i njihovo suzbijanje. Institut za kukuruz Zemun Polje i Školska knjiga Novi Sad 1-695, Beograd.

5. Čamprag, D., Jasnić, S., Kereši, T., Konstantinović, B., Lazić, S., Maširević, S., Petrić, D., Sekulić, R., Medić-Pap, S. (2010). 50 godina (1960-2010) univerzitetskog obrazovanja, naučne i stručne delatnosti u oblasti zaštite bilja - fitomedicine. Poljoprivredni fakultet, 1-326, Novi Sad.

6. CČanak, M., Parabućski, S., Kojić, M. (1978). Ilustrovana korovska flora Jugoslavije. Matica Srpska, 1-439, Novi Sad.

7. Čuturilo, S., Janjić, V. (1995). Enciklopedijski herbološki rečnik. Zavod za udžbenike i nastavna sredstva, 1-420, Beograd.

8. Čuturilo, S., Nikolić, B. (1986). Korovi lucerke i njihovo suzbijanje. Nolit,1-176, Beograd.

9. Čuturilo, S., Stojanović, D., Mijatović, K., Jeremić, M. (1972). Cuscuta trifoli i Cuscuta camestris i njihovo suzbijanje. NIP Mala poljoprivredna biblioteka, 1-40, Beograd.

10. Dražić, D., Konstatinović, B. (1996). Divlji sirak i njegovo suzbijanje. Poljoknjiga, 1-109, Beograd.

11. Đukić, D., Janjić, V., Moisuc, A., Kišgeci, J. (2004). Krmne, korovske, otrovne i lekovite biljke. Poljoprivredni fakultet 1-426, Novi Sad.

12. Đukić, D., Janjić, V., Stevović, V. (2006). Krmne i otrovne biljke. Poljoprivredni fakultet, Novi Sad, i Agronomski fakultet, Čačak, 1-215, Novi Sad.

13. Đukić, D., Stevović,V., Janjić, V. (2009). Proizvodnja stočne hrane na oranicama i travnjacima. Poljoprivredni fakultet, Novi Sad i Agronomski fakultet, 1-590, Čačak.

14. Gajić, D. (1950). Poznavanje korova i njihovo suzbijanje. Zadružna knjiga,1-92, Beograd. 
15. Gajić, D. (1955). Poznavanje korova i njihovo suzbijanje (drugo izdanje). Zadružna knjiga, 1-88, Beograd.

16. Gajić, D. (1963). Ekološka studija zubače (Cynodon dactylon). Kolarčev narodni univerzitet, 1-39, Beograd.

17. Gojković, G. (1981). Fitofarmakološka vrednost selektivnih herbicida u rasadnicima topole na aluvijuma Dunava. Institut za topolu, knjiga 11, 1-178, Novi Sad.

18. Janjić, V. (1977). Herbicidi. Institut za primenu nuklearne energije u poljoprivredi, 1-307, Beograd.

19. Janjić, V. (1982). Herbicidi - principi i metode određivanja. Privredno-finansijski vodič, 1-545, Beograd.

20. Janjić, V. (1985). Herbicidi. Naučna knjiga, 1-589, Beograd.

21. Janjić, V. (1987). Herbicidi - principi i metode određivanja (II izdanje). Naučna knjiga, 1-545, Beograd.

22. Janjić, V. (1994). Hormonski herbicidi. Izdavačko preduzeće „Nauka” i Institut za istraživanja u poljoprivredi „Srbija”, 1-278, Beograd.

23. Janjić, V. (1996). Triazinski herbicidi. Institut za istraživanja u poljoprivredi „Srbija” i Dizajn DB studio, 1- 476, Beograd.

24. Janjić, V.(1998). Herbicidi - parakvat i dikvat. Naučna knjiga, 1-99, Beograd.

25. Janjić, V. (1998). Karbamidi. Institut za istraživanja u poljoprivredi „Srbija” i Herbološko društvo Srbije, 1-264, Beograd.

26. Janjić, V., Kojić, M. (2000). Atlas korova. Institut za istraživanja u poljoprivredi „Srbija”, 1-189,Beograd.

27. Janjić, V. (2002). Sulfoniluree. Institut za istraživanja u poljoprivredi „Srbija”, Beograd, Akademija nauka i umjetnosti Republike Srpske, 1-172, Banja Luka.

28. Janjić, V., Kojić M. (2003). Atlas travnih korova. Institut za istraživanja u poljoprivredi „Srbija”, 1-144, Beograd.

29. Janjić, V., Mitrić, S. (2004). Pesticidi u poljoprivredi i šumarstvu. Poljoprivredni fakultet, 1-930, Banja Luka.

30. Janjić, V. (2005). Fitofarmacija. Društvo za zaštitu bilja Srbije, Institut za istraživanja u poljoprivredi „Srbija”, Beograd, Poljoprivredni fakultet, 1-1229, Banja Luka.

31. Janjić, V. Vrbničanin, S. (ur) (2007). Ambrozija. Herbološko društvo Srbije 1-118, Beograd.

32. Janjić, V., Elezović, I. (2008). Pesticidi u poljoprivredi i šumarstvu u Srbiji. Društvo za zaštitu bilja Srbije, 1-1137, Beograd.

33. Janjić, V. (2009). Mehanizam delovanja pesticida. Društvo za zaštitu bilja Srbije Beograd, Akademija nauka i umjetnosti Republike Srpske, 1-427, Banja Luka.

34. Janjić, V., Marković, Č., Keča, N. (2009). Šumarska fitofarmacija. Šumarski fakultet, 1-363, Beograd.

35. Janjić, V., Elezović, I. (2010). Pesticidi u poljoprivredi i šumarstvu 2010. Društvo za zaštitu bilja Srbije, 1-884, Beograd. 
36. Janjić, V. (2013). Obrazovanje, nauka i proizvodnja hrane. Akademija nauka i umjetnosti Republike Srpske. 1-680, Banja Luka.

37. Jarakula, B. (1933). Borba protiv korova. Savremena poljoprivreda. Novi Sad.

38. Jovanović, D. (1995). Delovanje herbicida na korove u zasadima jagode. Zajednica za voće i povrće Republike Srbije, 1-95, Beograd.

39. Jovanović, D. (1996). Korovi u voćnjacima. Partenon, 1-185, Beograd.

40. Kodinec, G. (1937). Korov i njegovo uništavanje. Seljački bukvar, 1-62, Beograd.

41. Kojić, M, Janjić, V., Jevtić, S. (1996). Korovi i herbicidi. Institut za istraživanja u poljoprivredi „Srbija”, NIP Radnička štampa, 1-175, Beograd.

42. Kojić, M. (1961). Korovi - osobine, vrste, suzbijanje. Zadružna knjiga, 1-103, Beograd.

43. Kojić, M. (1961). Biologija i suzbijanje korova (autorizovana skripta). Savez studenata Poljoprivrednog fakulteta,1-120, Beograd.

44. Kojić, M. (1967). Biologija i suzbijanje korova. Centar za unapređenje poljoprivredne proizvodnje SR Srbije, 1-226, Beograd.

45. Kojić, M., Stanković, A., Čanak, M. (1972). Korovi, biologija i suzbijanje. Institut za zaštitu bilja Poljoprivrednog fakulteta, 1 -398, Novi Sad.

46. Kojić, M. (1981). Određivanje korova u stadijumu klijanca. Nolit, 1-220, Beograd.

47. Kojić, M., Pejčinović, D. (1982). Korovska flora i vegetacija Kosova. Zavod za udžbenike i nastavna sredstva SAP Kosova, 1-193, Priština.

48. Kojić, M., Pejčinović, D., Gligorijević, S. (1983). Priručnik za određivanje korovske flore Kosova. Zavod za udžbenike i nastavna sredstva SAP Kosova, 1-292, Priština.

49. Kojić, M., Šinžar, B. (1985). Korovi. Naučna knjiga,1-332, Beograd.

50. Kojić, M. (1986). Mala korovska flora. Naučna knjiga, 1- 415, Beograd.

51. Kojić, M., Janjić, V. (1991). Otrovne biljke. Naučna knjiga, 1-279, Beograd.

52. Kojić, M., Milijić, S., Petrović, R., Ljiljak, N. (1993). Korovska vegetacija kukuruza Timočke Krajine. Institut za poljoprivredna i tehnološka istrašivanja, 1-74, Zaječar.

53. Kojić, M., Janjić, V. (1994). Osnovi herbologije. Izdavačko preduzeće „Nauka”, Institut za istraživanja u poljoprivredi „Srbija”, 1-492, Beograd.

54. Kojić, M., Janjić, V., Stepić, R.(1996). Korovi i njihovo suzbijanje. Birografika, 1-441, Subotica.

55. Kojić, M., Janjić, V. (ur) (1997). Savremeni problemi herbologije. Herbološko Društvo Srbije 1-199, Beograd.

56. Kojić, M., Mrfat-Vukelić, S., Vrbničanin, S., Dajić, Z., Stojanović, S. (2001). Korovi livada i pašnjaka Srbije. Institut za istraživanja u poljoprivredi „Srbija“, 1-366, Beograd.

57. Kojić, M., Mrfat-Vukelić, S., Dajić, Z., Đorđević-Milošević, S. (2004). Livade i pašnjaci Srbije. Institut za istraživanja u poljoprivredi Srbija 1-245, Beograd.

58. Kojić, M., Đurić, G., Janjić, V., Mitrić, S. (2005). Korovi voćnjaka Bosne i Hercegovine. Naučno voćarsko društvo Republike Srpske, 1-295, Banja Luka.

59. Konstantinović, B., Štrbac, P., Milošević, N. (1998). Zaštita soje od štetočina, bolesti i korova. Stylos, 1 -214, Novi Sad.

60. Konstantinović, B. (1999). Poznavanje i suzbijanje korova. Stylos, 1-299, Novi Sad. 
61. Konstantinović, B., Bošković, J. (2001). Biotehnologija u zaštiti bilja. Stylos,1-362, Novi Sad.

62. Konstantinović, B., Štrbac, P., Balaž, F. (2001). Zaštita šećerne repe od štetočina, bolesti i korova. Univerzitet u Novom Sadu, Poljoprivredni fakultet, Stylos,1-149, Novi Sad.

63. Konstantinović, B., Stojanović, S., Meseldžija, M. (2005). Biologija, ekologija i suzbijanje korova. Univerzitet u Novom Sadu, Poljoprivredni fakultet, 1-273, Novi Sad.

64. Konstantinović, B., Meseldžija, M., Maletin, S. (2007). Mogućnost primene herbicida i biljojedinh riba u uklanjanju korovske vegetacije iz kanalske mreže. Poglavlje u monografiji: Održive melioracije. Univerzitet u Novom Sadu, Poljoprivredni fakultet, 1 - 247, Novi Sad.

65. Konstantinović, B. (2008). Korovi i njihovo suzbijanje. Univerzitet u Novom Sadu, Poljoprivredni fakultet. 1-333, Novi Sad.

66. Konstantinović, B. (2012). Osnovi herbologije i herbicidi. Poljoprivredni fakultet, 1-456, Novi Sad.

67. Konstantinović, B., Konstantinović, Bo. (2014). Osnovi herbologije i korovi urbane sredine, Univerzitet u Novom Sadu, Poljoprivredni fakultet, 1-267, Novi Sad.

68. Kosovac, Z. (1971). Zaštita kukuruza od bolesti, štetočina i korova. Zadružna knjiga, $1-41$, Beograd.

69. Kovačević, D. (2008). Njivski korovi - biologija i suzbijanje. Poljoprivredni fakultet, $1-510$, Beograd.

70. Kovačević, Z., Mitrić, S. (2013). Invazivni i ekonomski štetni korovi na severnom delu teritorije Republike Srpske sa predlogom mjera kontrole. Poljoprivredni fakultet, 1-192, Banja Luka.

71. Kronaveter, Đ., Boža, P. (1994). Poznavanje semena najčešćih korova u semenarstvu. Institut za ratarstvo i povrtarstvo, Univerzitet u Novom Sadu, 1-61, Novi Sad.

72. Maksimović, S., Kojić, M., Janjić, V., Mrfat-Vukelić, S. (2005). Sportski i ukrasni travnjaci. Unija bioloških naučnih društava Jugoslavije, 1-206, Beograd.

73. Marinković, P., Šijak, M. (1983). Primena herbicida u šumskim rasadnicima, kulturama i plantažama. Jugoslovenski poljoprivredno-šumarski centar, 1-80, Beograd.

74. Martinović, M. (1942). Korov i njegovo suzbijanje. Poljoprivredna biblioteka, Beograd.

75. Meseldžija, M. (2006). Rezistentnost korovskih vrsta na triazinske herbicide. Zadužbina Andrejević, 1-74, Beograd.

76. Milenković, D. (1988). Efekti primene herbicida na bazi terbacila i pendimetalin prometrina u proizvodnji jednogodišnjih topolovih sadnica. Institut za topolu, 1-91, Novi Sad.

77. Milošević, D. (2009). Zaštita krompira - bolesti, štetočine, korovi, semenarstvo. Agronomski fakultet, 1-390, Čačak.

78. Milošević, M., Štrbac, P., Konstantinović, B. (1996). Krompir, bolesti, štetočine, korovi i njihovo suzbijanje. Feljton, 1-156, Novi Sad.

79. Milošević, V. (2011). Flora i vegetacija okopavina Mačve. Zadužbina Andrejević 1-74, Beograd. 
80. Mirić, M., Lekić, S., Petrović, R., Dražić, S., Stančić, I. (2004). Tehnologija proizvodnje semena. Društvo selekcionera i semenara Republike Srbije, 1-441, Beograd.

81. Mišović, M. (1972). Ispitivanje dejstva linurona i prometrina u različitim agroekološkim uslovima na organsku produkciju, kvalitet krompira i stepen efikasnosti u suzbijanju korova. Zbornik Poljoprivrednog fakulteta, 1-107, Zemun.

82. Molnar, I. (1995). Opšte ratarstvo. Feljton, 1-598, Novi Sad.

83. Nestorović, M., Konstantinović, B. (2011). Procena diverziteta korovske flore urbanih sredina, Prirodnjački muzej, 1-113, Beograd.

84. Novaković, V. (1962). Rezultati ogleda sa primenom herbicida za suzbijanju korova u nekim poljoprivrednim kulturama. Jugoslovenski savetodavni centar za poljoprivredu i šumarstvo, 1-54, Beograd.

85. Novaković, V., Hočevar, J., Čuturilo, S. (1963). Rezultati ogleda sa primenom simazina i atrazina na suzbijanju korova u kukuruzu i vinogradima. Jugoslovenski savetodavni centar za poljoprivredu i šumarstvo, 1-22, Beograd.

86. Ognjanović, R. (1997). Korovi pšenice i kukuruza i mere suzbijanja. Agonomski fakultet, 1- 128, Čačak.

87. Ostojić, N., Mihajlović, B. (1959). Korovi i njihovo suzbijanje. Zadružna knjiga, 1-98, Beograd.

88. Otašević, R., Mladenović, LJ. (1971). Zaštita ratarskih i povtrarskih kultura od bolesti, štetočina i korova. NIP Mala poljoprivredna biblioteka, 1- 64, Beograd.

89. Pejčinović, D. (1988). Ekološka studija korovske vegetacije Kosova. Akademija nauka i umetnosti Kosova, 1-85, Priština.

90. Stanković, A. (1969). Herbicidi I. Poljoprivredni fakultet, 1-189, Novi Sad.

91. Stanković, A. (1969). Herbicidi. Društvo za zaštitu bilja Srbije, 1-44, Novi Sad.

92. Stanković, A.(1972). Fitofarmacija I. Društvo za zaštitu bilja Srbije,1-311, Novi Sad.

93. Stanković, A.(1972). Fitofarmacija II. Društvo za zaštitu bilja Srbije,1-298, Novi Sad.

94. Stanković, A. (1972). Fitofarmacija III. Zaštita ratarskih kultura od korova, štetočina i parazitnih mikroorganizama. Društvo za zaštitu bilja Srbije, 1-395, Novi Sad.

95. Stanković, A. (1973). Zaštita duvana od štetočina, parazitnih mikroorganizama i korova, Poljoprivredni fakultet, Institut za zaštitu bilja , 1-52, Novi Sad.

96. Stanković, A. (1973). Fitofarmacija IV. Zaštita povrtarskih kultura od korova, štetočina i parazitskih mikroorganizama. Društvo za zaštitu bilja Srbije, 1-191, Novi Sad.

97. Stanković, A. (1974). Pesticidi u SFR Jugoslaviji. Centar za unapređenje poljoprivredne proizvodnje Srbije, 1-61, Beograd.

98. Stanković, A. (1976). Pesticidi u svetu i u SFRJ. Društvo za zaštitu bilja Srbije, 1-368, Novi Sad.

99. Stanković, A., Ostojić, N. (1955). Hemijska sredstva za zaštitu biljaka. Zadružna knjiga, 1-176, Beograd.

100. Stanković, A., Maceljski M. (1973). Zaštita šećerne repe od štetočina, parazitnih mikroorganizama i korova. Poljoprivredni fakultet, Institut za zaštitu bilja, 1-126, Novi Sad. 
101. Stanković, A., Šovljanski, R., Arsenović, M. (1978). Preporuke za primenu herbicida na hidromeliorativnim objektima sistema Dunav-Tisa- Dunav. Poljoprivredni fakultet, Institut za zaštitu bilja, 1-97, Novi Sad.

102. Stavretović, N. (2008). Kvalitetne vrste i korovi u travnjacima urbanog područja. Unija bioloških društava Srbije, 1-204, Beograd.

103. Stefanović, L., Simić, M. (2012). Korovi kukuruza i njihovo suzbijanje. Društvo genetičara Srbije, Institut za kukuruz, 1-350, Beograd.

104. Stefanović, L. Šinžar, B. (1993). Korovi kukuruza - biologija i suzbijanje. Institut za kukuruz Zemun Polje, 1-94, Beograd.

105. Stefanović, L. (1987). Zakorovljenost useva kukuruza severoistočne Srbije. Institut za kukuruz Zemun Polje, 1-135, Beograd.

106. Stefanović, L., Simić, M., Šinžar, B. (2011). Kontrola korova u agrosistemu kukuruza. Društvo genetičara Srbije i Institut za kukuruz Zemun Polje, 1-678, Beograd.

107. Stojanović, S., Butorac, B.,Vučković, M., Stanković, Ž., Kilibarda, M., Radak, LJ. (1994). Biljni svet kanala Vrbas-Bezdan. Univerzitet u Novom Sadu Prirodno-matematički fakultet, Institut za biologiju 1-110, Novi Sad.

108. Stojanović, S., Lazić, D., Knežević, A., Nikolić, LJ., Škorić, M., Kilibarda, P., Mišković, M., Bugarski R. (2007). Flora i vegetacija osnovne kanalske mreže HS DTD u Bačkoj. Poljoprivredni fakultet Novi Sad, JVP Vode Vojvodine 1-204, Novi Sad.

109. Šinžar, B., Janjić, V. (1995). Korovske biljke. Poljoknjiga, 1-296, Beograd.

110. Šovljanski, R., Konstantinović, B., Klokočar Šmit, Z. (2003). Akvatični korovi - suzbijanje i posledice. Poljoprivredni fakultet, Vode Vojvodine, 1-249, Novi Sad.

111. Štrbac, P., Konstatinović, B., Klokočar Šmit, Z. (1997). Lucerka - Zaštita od štetočina, bolesti i korova. Feljton, 1-147, Novi Sad.

112. Šumatić, N. (1997). Korovska flora i vegetacija Panonskog basena Republike Srpske. Prirodno-matematički fakultet, 1-9, Banja Luka.

113. Šumatić, N., Todorović, J., Komljenović. I., Marković, M. (1999). Atlas korova. Glas srpski, Šumarski fakultet, Poljoprivredni fakultet, 1-359, Banja Luka.

114. Šumatić, N., Topalović-Trivunić, LJ., Komljenović, I., Todorović, J. (2006). Najčešći korovi regije Banja Luka. Grafomark, 1-270, Laktaši.

115. Todorović, D. (1955). Opšte ratarstvo (zemljodelstvo) na osnovu agroekoloških načela. II prerađeno izdanje. Naučna knjiga, 1-797, Beograd.

116. Todorović, D. (1959). Imenik korovskog bilja Jugoslavije, Naučna knjiga, 1-98, Beograd.

117. Todorović, D. (1960). Opšte ratarstvo (zemljodelstvo) na osnovu agroekoloških načela. III prerađeno izdanje. Naučna knjiga, 1-797, Beograd.

118. Vasić, V., Konstantinović, B., Orlović, S. (2012). Weeds in Forestry and Possibilities of Their Control, Weeds. Andrew J. Price, 147-170.

119. Vrbničanin, S., Šinžar, B. (2003). Elementi herbologije sa praktikumom. IP Zavet i Poljprivredni fakultet, 1-322, Beograd. 


\section{Časopis Acta herbologica}

Najbolji pokazatelj razvijenosti i uspešnosti rada neke naučne discipline, u ovom slučaju herbologije, jeste činjenica da ta oblast ima svoj specijalizovan naučni časopis. Već više od 40 godina herbologija kao naučna disciplina ima svoj naučni časopis. U zajedničkoj državi Jugoslaviji (SFRJ), još 1971. godine izlazi prvi broj časopisa Fragmenta herbologica Croatica u Zagrebu, a glavni urednik je bio prof. dr Josip Kovačević. Posle dve godine izlaženja, časopis dobija naziv Fragmenta herbologica Jugoslavica. Časopis je izlazio dva puta godišnje, a više od 60 \% radova su bili radovi istraživača iz Srbije. Herbološko društvo Srbije 1992. godine, uz ogromnu aktivnost akademika Vaskrsija Janjića i prof. dr Momčila Kojića, pokreće časopis Acta herbologica (po raspadu SFRJ) koji i danas izlazi i objavljuje originalne i revijalne (pregledne) naučne radove iz svih oblasti nauke o korovima na srpskom jeziku i apstraktom na engleskom jeziku. Od 1999. godine časopis Acta herbologica izlazi u seriji Unije bioloških društava Jugoslavije, a od 2014. godine pošto Unija ne funkcioniše ponovo kao časopis Acta herbogica u izdanju Herbološkog društva Srbije. Časopis izlazi dva puta godišnje, a njegov glavni urednik od početka do 2008. godine bio je prof. dr Momčilo Kojić, a od 2008. godine je akademik prof.dr Vaskrsija Janjić. Do sada su izašla 44 broja, odnosno 22 volumena časopisa Acta herbologica u kojima je odštampano preko 150 radova na oko 1.300 stranica.

\section{Razvoj herbologije kao nastavne discipline}

Problem korova i primena mera za njihovo suzbijanje tek u novije vreme inkorporiran je i u nastavne programe visokoškolskog poljoprivrednog obrazovanja kao posebna disciplina. Do 1961. godine korovi su obrađivani samo u predmetu Opšte ratarstvo i to pretežno sa agrotehničkog i agroekološkog aspekta, što se i danas čini, i to samo na ratarskom odseku. Međutim, 1961. godina predstavlja u tom pogledu značajnu prekretnicu. Školske 1961/1962. godine prvi put u Jugoslaviji, a među prvima i u Evropi, na inicijativu akademika prof. dr Mladena Josifovića, uvodi se predmet Korovi i njihovo suzbijanje na Odseku za zaštitu bilja na Poljoprivrednom fakultetu u Zemunu. Kasnije ovaj predmet je uveden i na drugim fakultetima na odsecima za zaštitu bilja kao i na nekim višim poljoprivrednim školama. Prvi nastavnik na ovom predmetu, njegov utemeljivač, bio je prof. dr Momčilo Kojić, koji je organizovao nastavu (teoretsku i praktičnu) sastavio plan i program i izvodio nastavu desetinu godina, a kasnije je nastavu preuzeo prof. dr Borivoje Šinžar. Profesori M. Kojić i B.Šinžar su nastavnici botanike, koji su se u svom istraživačkom radu bavili i problemima korovske flore i vegetacije. Godine 1997. za nastavnika na predmetu Herbologija izabrana je docent dr Sava Ajder, sada Vrbničanin, koja se od početka svoje naučne i pedagoške aktivnosti razvijala u okvirima problematike korova, bila prvi asistent i prošla u ovoj disciplini kroz sva nastavna zvanja do redovnog profesora. Danas, pored redovnog profesora dr Save Vrbničanin u nastavi iz herboloških predmeta (Osnove herbologije, Osnove agrotehnike, Ekologija korova i drugim predmetima na master i doktorskim studijama), na Poljoprivrednom fakultetu Univerziteta u Beogradu, participira i doc. dr Dragana Božić. Od samog uvođenja ovog predmeta u nastavu 
1990. godine na Poljoprivrednom fakultetu u Novom Sadu, u samom početku, nastavu su izvodili prof. dr Momčilo Kojić i doc. dr Marija Arsenović, a zatim, u periodu 1991 - 2014 godine, prof. dr Branko Konstantinović. Isti predmet na Poljoprivrednom fakultetu u Banja Luci izvodio je akademik prof. dr Vaskrsija Janjić. Izvesni elementi koja se odnose na primenu herbicida obrađuju se na posebnoj naučnoj disciplini fitofarmaciji gde se iscrpno obrađuju herbicidi. Univerzitetsku nastavu koja se odnosi na herbicide zasnovali su i izvodili profesori Aleksandar Stanković (Novi Sad), i Radojica Kljajić (Zemun), a posle toga aktuelni nastavnici iz te oblasti profesori Milorad Šestović, Mileta Živanović, Vaskrsija Janjić, Ibrahim Elezović, Branko Konstantinović, Milica Mojašević, Maja Meseldžija, Sanja Lazić, Siniša Mitrić i Katarina Jovanović-Radovanov.

Pošto herbologija predstavlja relativno novu nastavnu disciplinu, koja nema dugu tradiciju, te predstavlja praktično nastavni predmet na početku svoga razvoja i utemeljivanja u programske okvire agronomskih studija, ukratko će se ukazati na njegove nastavne sadržaje, konstituisane u inicijalnoj fazi njegove egzistencije. Sadržaj nastavnog programa Herbologije na Odseku za zaštitu bilja Poljoprivrednog fakulteta u Zemunu, u osnovnim crtama je:

- Uvod (pojam i definicija korova, podela korova, biološke i ekološke osobine korovskih biljaka)

- Korovi u užem smislu (osnovne karakteristike, štete od korova, mogućnost upotrebe korova u korisne svrhe)

- Razmnožavanje korova (korovi sa samo polnim razmnožavanjem, osobine semena korovskih biljaka, vegetativno razmnožavanje i regeneracione sposobnosti vegetativnih organa korovskih biljaka, načini rasprostiranja korova)

- Varijabilnost korovskih biljaka (specijska i infraspecijska varijabilnost, biodiverzitet korvskih biljaka)

- Ekologija korova (autoekologija-ekološki faktori, sinekologija korova, antropogene biljne zajednice, pregled korovske vegetacije)

- Suzbijanje korova (indirektne mere suzbijanja korova, direktne mere suzbijanja korova - agrotehničke mere, fizičke mere, biološke mere, hemijske mere - herbicidi i njihova primena)

- Korovi u poljoprivrednim kulturama (korovi pšenice i drugih strnih žita, korovi kukuruza, korovi šećerne repe, korovi suncokreta, korovi soje, korovi povrtarskih useva, korovi lucerke, korovi voćnjaka, korovi vinograda, suzbijanje korova, posebno herbicidima, u pojedinim usevima i zasadima)

- Korovi u širem smislu (ruderalne biljke i ruderalna vegetacija, korovi na travnjacima, akvatični korovi, korovi u šumama, šumskim kulturama i rasadnicima, suzbijanje korova na nepoljoprivrednim površinama)

Tako je nastava na ovom i drugim poljoprivrednim fakultetima, uz ovaj ili veoma sličan nastavni program, konsolidovana. Teoretska nastava zasnovana je na savremenim dostignućima herbološke nauke, a praktične vežbe dobro osmišljene i obezbeđene potrebnim očiglednim materijalom. 
Desetak godina posle uvođenja herbologije u redovne četvorogodišnje studije, imajući u vidu potrebe daljeg obrazovanja i usavršavanja iz ove oblasti, kao i dostignuti stepen razvijenosti herbološke nauke, uvedene su dvogodišnje poslediplomske studije na Poljoprivrednom fakultetu u Zemuna, a zatim i u Novom Sadu. Detaljan prikaz urađenih i odbranjenih magistarskih radova i doktorskih disertacija dat je u ovom radu.

Aktuelni i akreditovani nastavni plan i program na osnovnim četvorogodišnjim studijama iz oblasti herbologije na Poljoprivrednom fakultetu Univerziteta u Beogradu i dalje je zadržao osnovni koncept i to:

- Dvadeset pet posto nastave fokusirano je na biologiji korova (uvod, definicija i klasifikacija korova; štete i koristi od korova; parazitski korovi; vegetativno i generativno razmnožavanje; načini širenja korova; invazivni procesi i rizici i štete od invazivnih korovskih vrsta po agroekosistem; diverzitet korovske flore i vegetacije);

- Dvadeset pet posto nastave fokusirano je na ekologiji korova (odnos korova prema sredinskim faktorima; interakcije kovor-usev kroz parazitske, kompetitivne i alelopatske odnose; pragovi štetnosti i kritično vreme za suzbijanje korova; pojam, mehanizam i tipovi rezistentnost korova i tolerantnost useva na herbicide, strategije za odlaganje pojave i prevazilaženje rezistentnosti korova na herbicide);

- Pedeset posto nastave je fokusirano na preventivne i direktne (agrotehničke, fizičke, biološke, hemijske) mere u suzbijanju korova. Poseban značaj se poklanja suzbijanju korova gde su uključene sve preventivne i direktne mere koje predstavljaju karike u lancu integralnih mera borbe protiv korova („many little hamers“, tj. „mnogo malih čekića") kako u pojedinim usevima i zasadima toko i na nepoljoprivrednim površinama (ruderalnim staništima, šumskim, vodenim i livadskim ekosistemima).

Takođe, studenti odseka za Fitomedicinu mogu dopuniti znanja iz herbologije kroz izborne predmete: Ekologija korova, Rezistentnost na pesticide i Selektivnost pesticida.

Na master studijama (peta godina studija) znanja iz oblasti herbologije studenti dobijaju kroz integralne predmete i to: Biljni karantin, Zaštita urbanog zelenila, Integralna zaštita njivskog bilja i Diverzitet korovske flore. Na doktorskim studijama (trogodišnjim) pored Metoda u fitomedicini doktorandi svoja znanja proširuju kroz niz izbornih predmeta gdu su pored ostalih i Herbologija, Invazivni korovi, Populaciona ekologija korova i Anatomija korovskih biljaka.

Ispiti na osnovnim, master i doktorskim studijama se polažu po principu ostvarenih bodova kroz položene testove, kolokvijume, odbranjene seminarske radove, aktivnosti na časovima i vežbama i na kraju na završnom usmenom ispitu.

Na Poljoprivrednom fakultetu, Univerziteta u Novom Sadu, herbologija je zastupljena na više smerova. Do 2014. godine, studenti Fitomedicine su na drugoj godini slušali predmet Osnovi herbologije, dok po novoj akreditaciji važećoj od školske 2014/2015, na drugoj godini ovog smera postoji predmet Osnovi herbologije, a na četvrtoj Posebna herbologija. Predmet istog imena slušaju i studenti treće godine Ratarsko-povrtarskog smera, dok studenti smera Agroekologija i zaštita životne sredine imaju premet Invazivne korovske vrste u petom 
semestru, a predmet Korovi urbanih sredina u osmom semestru. Takođe, studenti smera Fitomedicina mogu dopuniti znanja iz herbologije kroz izborne predmete: Prognoza pojave korovskih vrsta, Sinantropni organizmi i Akvatični ekosistemi. Na master studijama (peta godina studija) znanja iz oblasti herbologije studenti dobijaju kroz predmet Primenjena herbologija.

Na kraju, može se reći da nastava o korovima, iako je prvi put počela da se izvodi pre nešto više od 50 godina, po svojoj utemeljenosti i aktuelnosti ne zaostaje iza drugih nastavnih disciplina koje imaju veoma dugu tradiciju. Kada se svemu ovome doda da su za herbologiju obezbeđeni stalni univerzitetski udžbenici i praktikumi za praktične vežbe jasno proizlazi da je ova predmet potpuno konstituisan, stručno fundiran i dobio ozbiljan status u nastavnom planu studija na Odseku za zaštitu bilja (od 2007. godine po reformisanim studijama odsek je promenio naziv u Fitomedicina) na Poljoprivrednim fakultetima u našoj zemlji i postao potpuno ravnopravam sa drugim osnovnim predmetima koji imaju dugu tradiciju kao što su fitopatologija i entomologija.

\section{Pravci daljeg razvoja herbologije}

Da bi se herbologija, kao naučna, stručna i nastavna disciplina, ubrzano i pravilno razvijala u narednom periodu istraživači koji se bave ovom oblašću nauke moraju da se posvete sledećim, u svetski okvirima, aktuelnim pitanjima:

- Biologija i ekologija korovske flore i vegetacije

- Diverzitet i promene korovske flore i vegetacije

- Ekološki i genetički diverzitet korova

- Molekularna proučavanja korova u cilju očuvanja genofonda

- Populaciona genetika korova

- Kartiranje korova i izrada georeferenciranih baza podataka

- Modeliranje i predviđanje dinamike pojave invazivnih korova

- Mapiranje i razvoj softvera za prognozu pojave korova

- Biološke invazije

- Korovi parazitske cvetnice

- Interakcije usev-korov i pragovi štetnosti

- Razvoj i unapređenje agrotehničkih mera u funkciji suzbijanja korova

- Razvoj novih sistema zemljoradnje u funkciji kontrole korova

- Strategije kontrole korova u sistemu održive i organske biljne proizvodnje

- Značaj korova i herbicida u proizvodnji hrane i zaštiti životne sredine

- Racionalizacija i bezbednost u primeni herbicida

- Razvoj novih formulacija herbicida

- Multidisciplinarna istraživanja hemijskih, fizioloških, toksikoloških i ekotoksikoloških osobina herbicida

- Istraživanje mehanizma delovanja herbicida

- Modeliranje, prognoza zakorovljenosti i razvoj tehnologija za preciznu primenu herbicida

- Rezistentnosti korova/useva na herbicide 
- Multidisciplinarna istraživanja rezistentnosti korova i tolerantnosti useva na herbicide

- Razvoj i primena novih biotehnologija u funkciji kontrole korova

- Biološke mere borbe protiv korova

- Unapređenje integralnih mera borbe protiv korova

- Alternativne metode u borbi protiv korova

\section{LITERATURA}

Anonim: Jugoslovenska bibliografija o korovima - herbicidi. Hemizacija poljoprivrede, 16, 79 - 92, 1958. Anonim: Jugoslovenska bibliografija o korovima - biologija i ekologija, uništavanje korova na oraničnim površinama, sjemenarstvo i korovi, parazitski korovi, korovi travnjaka, koristi od korova i zakonske mjere u vezi suzbijanja korova. Hemizacija poljoprivrede, 23, 41 - 60, 1958.

Anonim: Deset godina Poljoprivrednog fakulteta u Novom Sadu 1954 - 1964. Poljoprivredni fakultet, Novi Sad, 1964.

Babović, M. (ur): Osamdeset godina Poljoprivrednog fakulteta Univerziteta u Beogradu (1919 - 1999). Poljoprivredni fakultet Univerzitet u Beogradu, Beograd, 1999.

Čamprag, D.: Doktorske disertacije iz oblasti zaštite bilja odbranjene u Jugoslaviji. Pesticidi, 3-4, 191-194, 1991.

Čamprag, D., Jasnić, S., Kereši, T., Konstantinović, B., Lazić, S., Maširević, S., Petrić, D., Sekulić, R., MedićPap, S.: 50 godina (1960-2010) univerzitetskog obrazovanja, naučne i stručne delatnosti u oblasti zaštite bilja - fitomedicine. Poljoprivredni fakultet, Novi Sad, 2010.

Dragović, S. (ur.): 60 godina u službi poljoprivrede (1938 - 1998). Naučni Institut za ratarstvo i povrtarstvo, Novi Sad, 1998.

Đukić, D. (ur.): Bibliografija I. Agronomski fakultet, Čačak, 1998.

Gvozdenović, D. (ur): Bibliografija II 1984 - 1994. Poljoprivredni fakultet, Novi Sad, 1994.

Gvozdenović, D. (ur.): Četrdesetpet godina Poljoprivrednog fakulteta u Novom Sadu (1954 - 1999). Poljoprivredni fakultet, Novi Sad, 1999.

Janjić, V., Mićić, N., Mirjanić, S., Matarugić, D., Ostojić, A.: 20 godina postojanja i rada Poljoprivrednog fakulteta u Banja Luci. Univerzitet u Banja Luci, Poljoprivredni fakultet Banja Luka, 2012.

Jasnić, S., Maširević, S. (ur): Naučno-obrazovni institut za zaštitu bilja Dr Pavle Vukasović. Trideset godina Poljoprivrednog fakulteta u Novom Sadu (1954-1984). Poljoprivredni fakultet, Novi Sad, 1984.

Jovanović, V. (ur.): Trideset godina Poljoprivrednog fakulteta u Novom Sadu (1954 - 1984). Poljoprivredni fakultet, Novi Sad, 1984.

Kljajić, R. (ur): Pedeset godina Poljoprivrednog fakulteta Univerziteta u Beogradu (1919-1969). Poljoprivredni fakultet Univerzitet u Beogradu, Beograd, 1969.

Kojić, M., Janjić, V.: Razvoj herbologije u Jugoslaviji. Zbornik radova VI Kongresa o korovima, Banja Koviljača, 2000.

Konstantinović, B.: Institut za zaštitu bilja "Dr Pavle Vukasović". Četrdesetpet godina Poljoprivrednog fakulteta u Novom Sadu (1954 - 1999). Poljoprivredni fakultet, Novi Sad, 1999.

Kovačević, J. (ur): Jugoslovenska bibliografija literature o korovima za vremensko razdoblje 1958-1973 godine. Matica Srpska, Novi Sad, 1979.

Krajinović, M.(ur): Pedeset godina Poljoprivrednog fakulteta u Novom Sadu (1954-2004). Poljoprivredni fakultet, Novi Sad, 2004.

Krajinović, M. (ur): Biografije nastavnika i stručnjaka Poljoprivrednog fakulteta u Novom Sadu (1954 2004). Poljoprivredni fakultet, Novi Sad, 2006. 
Maceljski, M.: 40 godina posljediplomske nastave i 20 godina redovne nastave iz zaštite bilja na Agronomskom fakultetu u Zagrebu. Glasnik biljne zaštite 4, 257-258, 2003.

Marković, M. (ur): Monografija Poljoprivrednog instituta Republike Srpske - 65 godina naučno-istraživačkog i praktičnog rada na unapređenju poljoprivrede (1947-2012) Poljoprivredni institut Republike Srpske, Banja Luka, 2012.

Mihaljev, I. (ur): Četrdeset godina Poljoprivrednog fakulteta u Novom Sadu (1954-1994). Poljoprivredni fakultet, Novi Sad, 1994.

Nedović, B. (ur): Poljoprivredni fakultet Banja Luka 1992-1997. Univerzitet u Banja Luci, Poljoprivredni fakultet, Banja Luka, 1998.

Nikolić, V.: Bibliografija radova iz oblasti zaštite bilja objavljenih u FNRJ od 1945-1952. Institut za zaštitu bilja, Beograd, 1954.

Perić, I., Janjić., V., Nešković, N., Gašić, S., Perić, P., Marčić, D., Vukša, M., Duduk, B., Radivojević, LJ., Tomašević, A., Klarić, S., Marinkov-Jovanović, D. Grba, R.: Pola veka razvoja nauke o pesticidima, zaštiti bilja i životnoj sredini. Institut za pesticide i zaštitu životne sredine, Beograd, 2009.

Petrić, D. (ur): Institut za zaštitu bilja “Dr Pavle Vukasović”. Četrdeset godina Poljoprivrednog fakulteta u Novom Sadu (1954-1994). Poljoprivredni fakultet, Novi Sad, 1994.

Petrić, D. (ur): Bibliografija III (1994 - 2004). Poljoprivredni fakultet, Novi Sad, 1994.

Petrović-Zečević, LJ. (ur): Bibliografija Republike Srpske. Narodna i Univerzitetska biblioteka Republike Srpske, Banja Luka, 2011.

Ranđelović, V. (ur): Šezdeset godina Poljoprivrednog fakulteta Univerziteta u Beogradu (1919-1979). Poljoprivredni fakultet Univerzitet u Beogradu, Beograd, 1979.

Ranđelović, V. (ur): Sedamdeset godina Poljoprivrednog fakulteta Univerziteta u Beogradu (1919-1989). Poljoprivredni fakultet Univerzitet u Beogradu, Beograd, 1989.

Rudić, D. (ur): Devedeset godina Poljoprivrednog fakulteta Univerziteta u Beogradu (1919-2009). Poljoprivredni fakultet Univerzitet u Beogradu, Beograd, 2009.

Spasojević, M. (ur): Bibliografija radova. Agronomski fakultet, Čačak, 2008.

Šijak, M., Dinić, A.: Bibliografija objavljenih radova u časopisu Šumarstvo (1948-2007) povodom 60 godišnjice osnivanja. Udruženje šumarskih inženjera i tehničara Srbije, Beograd, 2007.

Vasiljević, LJ. (ur): Bibliografija zaštite bilja Jugoslavije (od 1763 do 1989 god). Savez društava za zaštitu bilja Jugoslavije, Beograd, 1991.

Vrbničanin, S., Kojić, M.: Biološka i ekološka istraživanja korova na području Srbije (razvoj, sadašnje stanje i perspektive). Zbornik radova VI Kongresa o korovima, Banja Koviljača, 2002.

Vrbničanin, S., Janjić, V.: Istorijat i pravci daljeg razvoja herbologije kao naučne i obrazovne discipline. Zbornik rezimea radova XIV simpozijuma o zaštiti bilja i IX kongresa o korovima, Zlatibor, 2012.

Vrbničanin, S.: Weed Research in Serbia. EWRS News letter (http://www.ewrs.org), 2013.

Vrbničanin, S.: Weed Research in Serbia. Join Workshop of the EWRS Working Groups: Novel and Sustainable Weed Management in Arid and Semi-arid Agro Ecosystems and Weed Mapping. Chania Crete, Greece. Book of Abstracts, 38-39 (keynote address), 2013.

Vučić, N. (ur): Bibliografija I 1954-1984. Poljoprivredni fakultet, Novi Sad, 1984.

Vukša, P. (ur): Univerzitetsko obrazovanje u oblasti zaštite bilja - fitomedicine. Univerzitet u Beogradu, Poljoprivredni fakultet, Institut za fitomedicinu, Beograd, 2009. 